\title{
Methods for Estimating Regional Skewness of Annual Peak Flows in Parts of Eastern New York and Pennsylvania, Based on Data Through Water Year 2013
}

Scientific Investigations Report 2021-5015 



\section{Methods for Estimating Regional Skewness of Annual Peak Flows in Parts of Eastern New York and Pennsylvania, Based on Data Through Water Year 2013}

By Andrea G. Veilleux and Daniel M. Wagner

Scientific Investigations Report 2021-5015 


\section{U.S. Geological Survey, Reston, Virginia: 2021}

For more information on the USGS - the Federal source for science about the Earth, its natural and living resources, natural hazards, and the environment—visit https://www.usgs.gov or call 1-888-ASK-USGS.

For an overview of USGS information products, including maps, imagery, and publications, visit https://store.usgs.gov/.

Any use of trade, firm, or product names is for descriptive purposes only and does not imply endorsement by the U.S. Government.

Although this information product, for the most part, is in the public domain, it also may contain copyrighted materials as noted in the text. Permission to reproduce copyrighted items must be secured from the copyright owner.

Suggested citation:

Veilleux, A.G., and Wagner, D.M., 2021, Methods for estimating regional skewness of annual peak flows in parts of eastern New York and Pennsylvania, based on data through water year 2013: U.S. Geological Survey Scientific Investigations Report 2021-5015, 38 p., https://doi.org/10.3133/sir20215015.

Associated data for this publication:

Wagner, D.M., and Veilleux, A.G., 2021, Regional flood skew for parts of the mid-Atlantic region (hydrologic unit 02) in eastern New York and Pennsylvania: U.S. Geological Survey data release, https://doi.org/10.5066/P9PGALOD.

ISSN 2328-0328 (online) 


\section{Contents}

Abstract

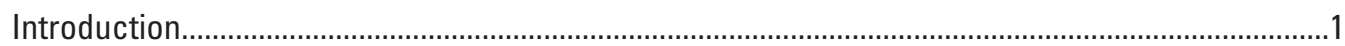

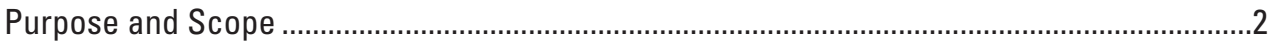

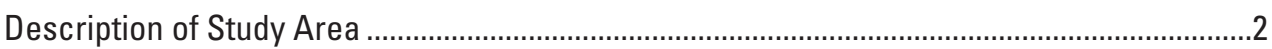

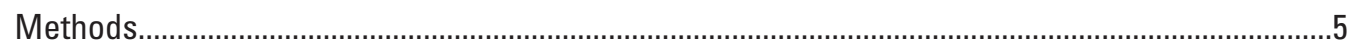

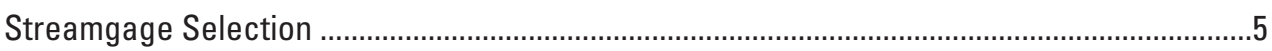

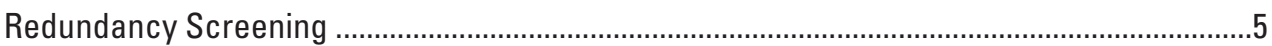

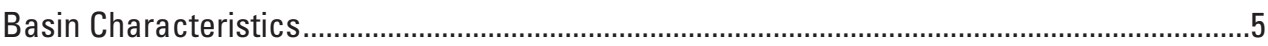

Annual Exceedance Probability Analyses................................................................................

Bayesian Weighted Least Squares/Bayesian Generalized Least Squares Analysis ................6

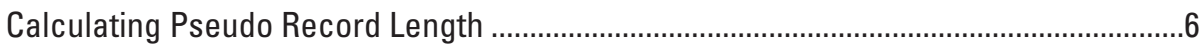

Removing the Bias of the At-Site Estimators …………...................................................

Estimating the Mean Square Error of the Skew ..........................................................11

Developing a Cross-Correlation Model..........................................................................11

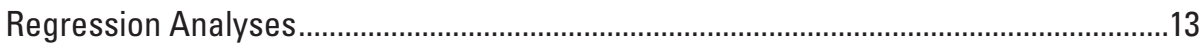

Ordinary Least Squares Analysis ..........................................................................13

Weighted Least Squares Analysis ..........................................................................13

Generalized Least Squares Analysis ................................................................14

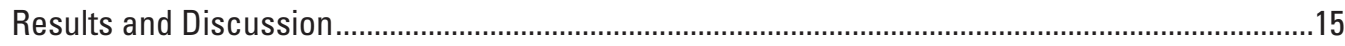

Final Bayesian Weighted Least Squares/Bayesian Generalized Least Squares Model ........15

Bayesian Weighted Least Squares/Bayesian Generalized Least Squares Regression

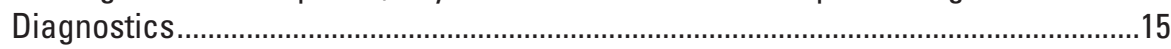

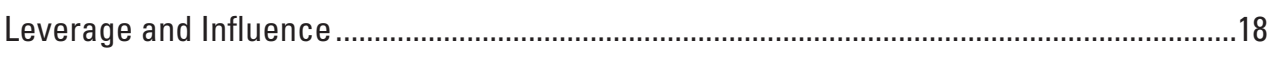

Summary

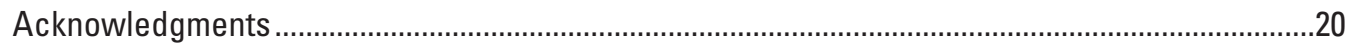

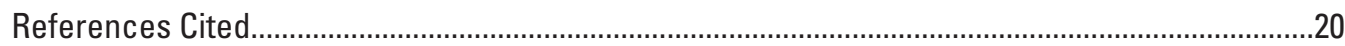

Appendix 1. Assessment of a Regional Skew Model for Parts of Eastern New York and

Pennsylvania by Using Monte Carlo Simulations .....................................................................33

\section{Figures}

1. Maps of the study area in eastern New York and Pennsylvania ........................................

2. Map showing the pseudo record lengths $\left(P_{R L}\right)$ of streamgages that were used in the regional skew analysis for parts of eastern New York and Pennsylvania ..............9

3. Map showing unbiased station skew of streamgages used in the regional skew analysis for parts of eastern New York and Pennsylvania ...............................................10

4. Graphs showing cross correlation of annual peak flows in the study area ....................12

5. Map showing residuals from constant model of skew for 183 streamgages that were used in the regional skew analysis for parts of eastern New York and Pennsylvania 


\section{Tables}

1. Streamgages that were considered for use in the regional skew analysis for parts of eastern New York and Pennsylvania

2. Basin characteristics considered for use as explanatory variables in the regional skew analysis

3. Regional skew model and model fit for parts of eastern New York and Pennsylvania

4. Pseudo analysis of variance (pseudo ANOVA) table for the constant model of regional skew in parts of eastern New York and Pennsylvania

5. Streamgages with high influence on the constant model of regional skew

\section{Conversion Factors}

International System of Units to U.S. customary units

\begin{tabular}{lcl}
\hline \multicolumn{1}{c}{ Multiply } & By & To obtain \\
\hline & Length & \\
\hline centimeter $(\mathrm{cm})$ & 0.3937 & inch $(\mathrm{in})$. \\
kilometer $(\mathrm{km})$ & 0.6214 & mile $(\mathrm{mi})$ \\
\hline & Volume & \\
\hline cubic meter $\left(\mathrm{m}^{3}\right)$ & 35.31 & cubic foot $\left(\mathrm{ft}^{3}\right)$ \\
\hline & Flow rate & \\
\hline cubic meter per second $\left(\mathrm{m}^{3} / \mathrm{s}\right)$ & 35.31 & cubic foot per second $\left(\mathrm{ft}^{3} / \mathrm{s}\right)$ \\
\hline
\end{tabular}

\section{Datum}

Vertical coordinate information is referenced to the North American Vertical Datum of 1988 (NAVD 88).

Horizontal coordinate information is referenced to the North American Datum of 1983 (NAD 83). 


\title{
Abbreviations
}

\author{
AEP annual exceedance probability \\ ASEV average sampling error variance \\ $A V P_{\text {new }} \quad$ average variance of prediction at a new streamgage \\ B17B Bulletin 17B (see Interagency Advisory Committee on Water Data, 1982) \\ B17C Bulletin 17C (see England and others, 2018) \\ B-GLS Bayesian generalized least squares \\ B-WLS Bayesian weighted least squares \\ $D A R \quad$ drainage area ratio \\ EMA expected moments algorithm \\ EVR error variance ratio \\ GAGES-II Geospatial Attributes of Gages for Evaluating Streamflow, Version II \\ GIS geographic information system \\ LP-III log-Pearson Type III distribution \\ $M B V^{*} \quad$ misrepresentation of the beta variance \\ MGBT multiple Grubbs-Beck test \\ MSE mean square error \\ $\operatorname{MSE}(\hat{G})$ mean squared error of skew \\ NWIS National Water Information System \\ OLS ordinary least squares \\ PILF potentially influential low flood \\ $P_{R L} \quad$ pseudo record length \\ Pseudo ANOVA pseudo analysis of variance \\ $S D \quad$ standardized distance \\ USGS U.S. Geological Survey
}





\title{
Methods for Estimating Regional Skewness of Annual Peak Flows in Parts of Eastern New York and Pennsylvania, Based on Data Through Water Year 2013
}

\author{
By Andrea G. Veilleux and Daniel M. Wagner
}

\section{Abstract}

Bulletin 17C (B17C) recommends fitting the log-Pearson Type III (LP-III) distribution to a series of annual peak flows at a streamgage by using the method of moments. The third moment, the skewness coefficient (or skew), is important because the magnitudes of annual exceedance probability (AEP) flows estimated by using the LP-III distribution are affected by the skew; interest is focused on the right-hand tail of the distribution, which represents the larger annual peak flows that correspond to small AEPs. For streamgages having modest record lengths, the skew is sensitive to extreme events like large floods, which cause a sample to be highly asymmetrical or "skewed." For this reason, B17C recommends using a weighted-average skew computed from the skew of the annual peak flows for a given streamgage and a regional skew. This report presents an estimate of regional skew for a study area encompassing parts of eastern New York and Pennsylvania. A total of 232 candidate U.S. Geological Survey streamgages that were unaffected by extensive regulation, diversion, urbanization, or channelization were considered for use in the skew analysis; after screening for redundancy and pseudo record length $\left(P_{R L}\right)$ of at least 36 years, 183 streamgages were selected for use in the study.

Flood frequencies for candidate streamgages were analyzed by employing the expected moments algorithm, which extends the method of moments so that it can accommodate interval, censored, and historical/paleo flow data, as well as the multiple Grubbs-Beck test to identify potentially influential low floods in the data series. Bayesian weighted least squares/Bayesian generalized least squares regression was used to develop a regional skew model for the study area that would incorporate possible variables (basin characteristics) to explain the variation in skew in the study area. Ten basin characteristics were considered as possible explanatory variables; however, none produced a pseudo coefficient of determination (pseudo $R_{\delta}^{2}$ ) greater than 1 percent; as a result, these characteristics did not help to explain the variation in skew in the study area. Therefore, a constant model that had a regional skew coefficient of 0.32 and an average variance of prediction at a new streamgage $\left(A V P_{n e w}\right.$, which corresponds to the mean square error [MSE] of 0.11) was selected. The $A V P_{\text {new }}$ corresponds to an effective record length of 68 years, a marked improvement over the Bulletin 17B national skew map, whose reported MSE of 0.302 indicated a corresponding effective record length of only 17 years.

\section{Introduction}

Flood-frequency analysis of annual peak flows at streamflow-gaging stations (hereafter referred to as "streamgages") provides engineers, hydrologists, and many others estimates of the magnitudes and frequencies of floods for planning, design, and management of infrastructure along rivers and streams. The Subcommittee on Hydrology of the Federal Advisory Committee on Water Information recently published Bulletin 17C (herein referred to as "B17C"; England and others, 2018), which comprises updated guidelines for flood-frequency analysis. The bulletin recommends the use of the log-Pearson Type III (LP-III) distribution to fit a time series of annual peak flows measured by a streamgage to obtain estimates of flows corresponding to various annual exceedance probabilities (AEPs). In the case of floodfrequency analysis, the LP-III distribution is described by three moments: the mean, the standard deviation, and the skewness coefficient of the logarithms of the flows. The third moment, the skewness coefficient (hereafter referred to as the "skew"), is a measure of the asymmetry of the distribution as shown by the thicknesses of the tails of the distribution. In flood-frequency analysis, the skew is important because the magnitudes of AEP flows estimated by using the LP-III distribution are affected by the skews of the annual peak flows at specific streamgages (hereafter referred to as "station skew"); interest is focused on the right-hand tail of the distribution, which represents annual peak flows corresponding to small AEPs of the larger flood flows.

For streamgages having modest record lengths, approximately in the range of 25 to 100 years, the skew is sensitive to unusually large or small annual peak flows because they cause a sample of such flows to be asymmetrical or skewed (Griffis and Stedinger, 2007). Thus, B17C guidelines recommend 
using a weighted-average skew that is computed from the skew of the station's annual peak flows and the regional skew. Using the weighted-average skew reduces the sensitivity of the station skew to extreme events, particularly for streamgages with short record lengths of less than approximately 25 years.

The $\mathrm{B} 17 \mathrm{C}$ guidelines recommend using the Bayesian weighted least squares/Bayesian generalized least squares (B-WLS/B-GLS) method to estimate regional skew (England and others, 2018, p. 30). Using this procedure, the regional skew is estimated based on the station skew of the logarithms of annual peak-flow data. The B-WLS/B-GLS procedure first uses an ordinary least squares (OLS) regression analysis to generate an initial regional-skew model that is used to compute the variance of the station skew for each streamgage. Next, B-WLS is used to generate estimators of the regional skew model parameters. Finally, B-GLS is used to estimate the precision of the $\mathrm{B}-\mathrm{WLS}$ parameter values, to estimate the model error variance and its precision, and to compute some diagnostic statistics. The expected moments algorithm (EMA; Cohn and others, 1997) is a generalization of the method-ofmoments approach for flood-frequency analysis of annual peak flows from streamgages recommended by B17C. The B-WLS/B-GLS method can account for the complexities introduced by EMA and the cross correlation between annual peak flows at pairs of streamgages (Veilleux, 2011; Veilleux and others, 2011).

To date, the B-WLS/B-GLS method has been used to generate estimates of regional skew for several regions around the Nation (Parrett and others, 2011; Eash and others, 2013; Olson, 2014; Paretti and others, 2014; Southard and Veilleux, 2014; Curran and others, 2016; Mastin and others, 2016; Wagner and others, 2016; Veilleux and Wagner, 2019). In this study, the B-WLS/B-GLS procedure was used to estimate skew for a region encompassing parts of eastern New York and Pennsylvania (fig. 1) to improve estimates of regional skew and flows corresponding to various AEPs across the region.

\section{Purpose and Scope}

The purpose of this report is to present the results of a B-WLS/B-GLS analysis of regional skew for parts of eastern New York and Pennsylvania (fig. $1 A$ ). The scope of the project includes 183 streamgages in the Mid-Atlantic region (hydrologic units 0202, 0204, 0205, 0206, and 0207) and in the Connecticut Coastal region (hydrologic unit 0110) located in the States of Connecticut, Maryland, Massachusetts, New Jersey, New York, Pennsylvania, Vermont, Virginia, and West Virginia (fig. $1 B$ ). The number of available streamgages that were unaffected by regulation or urbanization in hydrologic unit 0203 in southern New York and northern New Jersey (the Lower Hudson-Long Island region) was insufficient; therefore, the regional skew does not apply there. Floodfrequency analyses for the 183 streamgages were based on annual peak-flow data through water year 2013 (a water year is described as the period of October 1-September 30 and is named for the year in which it ends) and were performed using the U.S. Geological Survey (USGS) peak-flow analysis software (PeakFQ version 7.3; Veilleux and others, 2014; https://water.usgs.gov/software/PeakFQ/). The results were used to analyze the regional skew.

A summary of information for each streamgage used in the regional skew analysis and a description of the basin characteristics considered as potential explanatory variables in the study are provided in the tables in this report. PeakFQ input files (.txt), PeakFQ setup files (.psf), PeakFQ output files (.PRT), a geographic information system (GIS) shapefile (containing streamgage information, basin characteristics, results of flood-frequency analysis, and B-WLS/B-GLS results), a comma-separated values file containing the attributes of the GIS shapefile, and the corresponding metadata are provided in a data release associated with this report (Wagner and Veilleux, 2021).

\section{Description of Study Area}

The study area encompasses part of the Mid-Atlantic region (hydrologic unit 02) and the Connecticut Coastal region (hydrologic unit 0110) and includes parts of the States of New York and Pennsylvania (fig. 1A). The study area encompasses 49,817 square miles and spans approximately 300 miles from north to south (from northern New York to the southern border of Pennsylvania) and approximately 200 miles from east to west (from west-central Pennsylvania to the eastern border of New York).

The study area is located entirely within the Appalachian Highlands physiographic division, which is characterized by hilly to mountainous terrain of the Adirondack, Valley and Ridge, Appalachian Plateaus, Piedmont, and New England physiographic provinces (Fenneman, 1938). Basin-averaged mean annual precipitation for streamgages in the study area ranged from 35 to 63 inches (88 to 160 centimeters; Falcone, 2011). Based on the 2011 National Land Cover Database, the study area is approximately 60 percent forested, 22 percent agricultural (crops and pasture), 10 percent developed, and 3 percent wetlands, with the remaining 5 percent including open water, barren land, shrub/scrub, and grassland/ herbaceous categories (Homer and others, 2015). 


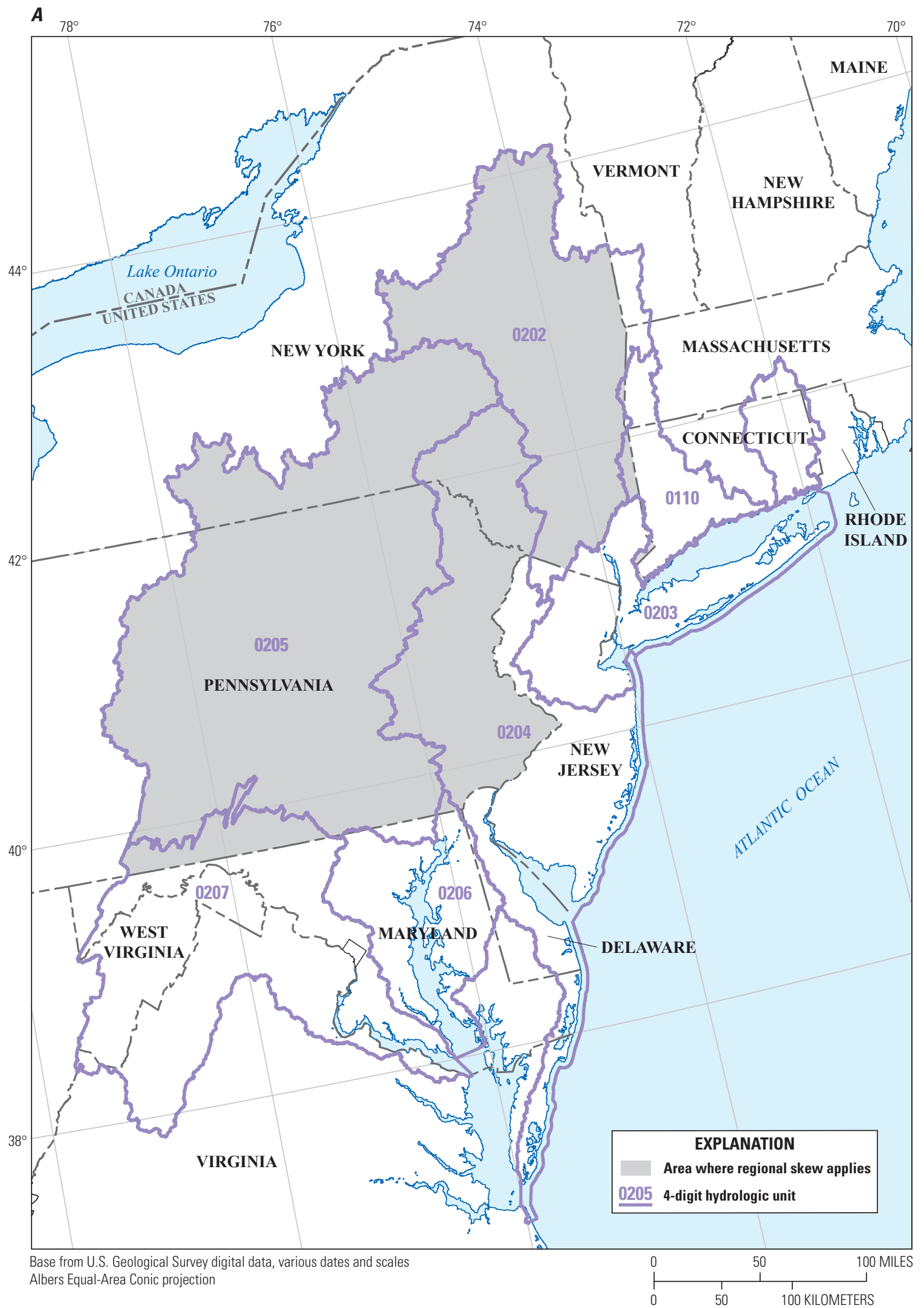

Figure 1. Maps of the study area in eastern New York and Pennsylvania showing $(A)$ 4-digit hydrologic units (U.S. Geological Survey, 2019), and (B) locations of the 183 streamgages used in the skew analysis. 


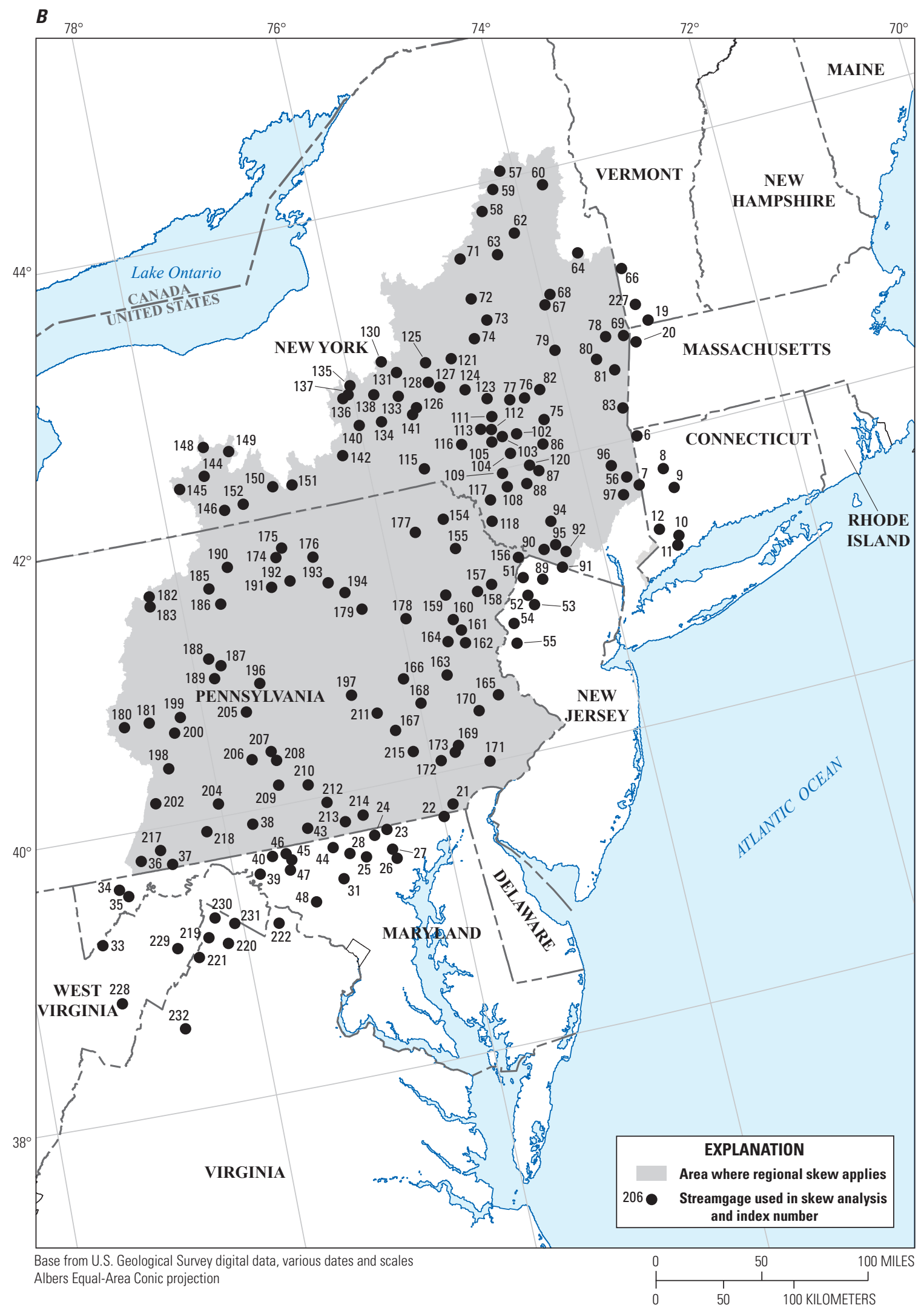

Figure 1.-Continued 


\section{Methods}

\section{Streamgage Selection}

A suite of 232 candidate USGS streamgages were considered for use in the regional skew analysis (table 1, which follows the "References Cited"). Annual peak flows for these streamgages were obtained from the USGS National Water Information System (NWIS; U.S. Geological Survey, 2018). Only streamgage records that were unaffected by extensive regulation, diversion, urbanization, or channelization (based on coding of annual peaks in the peak-flow files) and that had approximately 25 or more gaged peaks were considered for use in the regional skew analysis. Using these criteria, USGS employees who had local knowledge and experience in New York and Pennsylvania selected the candidate streamgages. A review of the study area boundary found that 17 streamgages were located outside the study area and were removed, after which 215 were left for use in the regional skew study (table 1). After that, streamgages that were deemed redundant were then screened and removed from the larger dataset (see the "Redundancy Screening" section for more information).

\section{Redundancy Screening}

Two streamgages may be redundant if their drainage basins are nested and similar in size; the drainage basins are considered nested if one entire drainage area is inside the other. If streamgages are redundant, a statistical analysis incorporating data from both streamgages incorrectly represents the information content in the regional dataset (Gruber and Stedinger, 2008). Instead of providing two spatially independent observations that depict how the characteristics of each basin are related to skew, the basins will be assumed to exhibit similar hydrologic responses to a given storm and thus represent only one spatial observation. To determine whether two streamgages are redundant and thus represent the same watershed for the purposes of developing a regional hydrologic model, two types of information are considered: (1) the standardized distance $(S D)$ between the centroids of the basins and (2) the ratio of the drainage areas of the basins.

The $S D$ between two basin centroids is used to determine the likelihood that the basins are redundant. The $S D$ is defined as

$$
S D_{i j}=\frac{D_{i j}}{\sqrt{0.5\left(D R N A R E A_{i}+D R N A R E A_{j}\right)}},
$$

where

$D_{i j} \quad$ is the distance between centroids of basin $i$ and basin $j$, in miles;

$D_{R N A R E A_{i}} \quad$ is the drainage area at streamgage $i$, in square miles; and

$D R N A R E A_{j} \quad$ is the drainage area at streamgage $j$, in square miles.
The drainage area ratio $(D A R)$ is used to determine if two nested basins are sufficiently similar in size that they represent the same watershed for the purposes of developing a regional hydrologic model (Veilleux, 2009). The DAR is defined as

$$
D A R=\operatorname{Max}\left[\frac{D R N A R E A_{i}}{D R N A R E A_{j}}, \frac{D R N A R E A_{j}}{D R N A R E A_{i}}\right],
$$

where

$D A R \quad$ is the Max (maximum) of the two values in brackets,

$D R N A R E A_{i} \quad$ is the drainage area at streamgage $i$, and $D R N A R E A_{j} \quad$ is the drainage area at streamgage $j$.

Streamgage pairs having a $S D$ less than or equal to 0.50 and a $D A R$ less than or equal to 5.0 are likely to be redundant for purposes of determining regional skew (Veilleux, 2009). If the $D A R$ is large enough, even nested streamgages will reflect different hydrologic responses because storms of different sizes and durations typically affect sites differently.

All possible combinations of streamgage pairs from the 215 streamgages were considered in the redundancy analysis. All streamgage pairs with a $S D \leq 0.5$ and a $D A R \leq 5.0$ were identified as possibly redundant. The drainage area of each streamgage was then investigated to determine if one of the two drainage areas was nested inside the other; if this was true, the preference was generally for the streamgage that had the smaller drainage area and the longer record length. The procedure identified 24 possibly redundant streamgage pairs; of these, 17 streamgages were found to be redundant and were removed from the analysis.

\section{Basin Characteristics}

Basin characteristics for the streamgages used in the skew analysis were either obtained from the USGS Geospatial Attributes of Gages for Evaluating Streamflow, Version II (GAGES-II) database or were generated. The GAGES-II database consists of a subset of USGS streamgages that have at least 20 years of streamflow record since 1950 or that were active as of water year 2009 and whose watersheds lie within the United States (Falcone, 2011). For streamgages that were used in the skew analysis but were not in the GAGES-II database, the suite of basin characteristics was generated by using the ArcHydro package in Esri ArcGIS software version 10.3.1 (Environmental Systems Research Institute, 2009; Eash and others, 2013; Wagner and others, 2016). This procedure ensured that a consistent suite of basin characteristics was available for all of the streamgages used in the skew analysis.

Basin characteristics were selected to potentially explain the variation in skew in the study area. These included morphometric (drainage area, latitude and longitude of basin centroid, mean basin slope, mean basin elevation, and basin compactness ratio), climatological (basin-average mean annual 
precipitation), and pedologic or geologic (areal percentages of open water and forest, and average soil permeability) characteristics (table 2).

\section{Annual Exceedance Probability Analyses}

To estimate regional skew for parts of eastern New York and Pennsylvania, a flood-frequency analysis must first be conducted for each streamgage to determine the station skew and its associated mean square error (MSE). The B17C guidelines recommend fitting the LP-III distribution to a series of annual peak flows at a streamgage by using the method of moments (England and others, 2018). In doing so, it is recommended that EMA is employed to extend the method of moments to accommodate interval, censored, and historical or paleo flood data, as well as the use of the multiple GrubbsBeck test (MGBT) to identify potentially influential low floods (PILFs) in the data series. In this study, the USGS software PeakFQ version 7.3 was used to analyze the flood frequencies (Veilleux and others, 2014).

Hydrologists in the USGS Water Science Centers in New York and Pennsylvania used EMA with PeakFQ version 7.3 for candidate streamgages in their States and for candidate streamgages in the surrounding states of Connecticut, Maryland, Massachusetts, New Jersey, Vermont, Virginia, and West Virginia. Flood frequencies were analyzed by using the station-skew option in PeakFQ software and, with few exceptions (such as a fixed threshold for PILFs that yielded a superior fit of the flood-frequency model to the dataset), the MGBT for PILFs. Historical peaks were included in the analysis; annual peak flows coded as urban or regulated were not. Hydrologists in New York and Pennsylvania assigned perception thresholds to each period of record (including historical and missing periods as well as periods of crest-stage gage operation) and assigned flow intervals to uncertain annual peak flows as appropriate.

\section{Bayesian Weighted Least Squares/Bayesian Generalized Least Squares Analysis}

Prior to analyzing regional skew by the B-WLS/B-GLS method, three preliminary steps were completed: (1) calculation of the pseudo record length for each streamgage, given the number of censored observations and concurrent record lengths; (2) removal of structural bias in the estimate of station skew and its MSE; and (3) development of a cross-correlation model of concurrent annual peak flows between streamgages.

\section{Calculating Pseudo Record Length}

The pseudo record length of the annual peak-flow series at each streamgage is used in the regional skew study in several steps, including unbiasing the station skew and its mean square error, determining the concurrent record length between two streamgages, and computing the cross correlation of the station skews. Because the dataset includes censored data and historical information, the effective record length used to compute the precision of the skewness estimators is no longer simply the number of annual peak flows at a streamgage. Instead, a more complex calculation based on the availability of historical information and censored values is used. Whereas historical information and records of censored peaks provide valuable information, they often provide less information than records of an equal number of years of gaged peaks (Stedinger and Cohn, 1986). The calculations described in the following paragraphs yield a pseudo record length $\left(P_{R L}\right)$ associated with skew, which appropriately accounts for all types of peak-flow data available from a streamgage. If no interval, censored, and (or) historical data are present in the annual peak-flow record of a streamgage, $P_{R L}$ is equal to the gaged record length.

The $P_{R L}$ is defined as the number of years of gaged record that would be required to yield the same mean squared error of the skew $(\operatorname{MSE}(\hat{G}))$ as would the combination of the historical and gaged records that are actually available at a streamgage. Thus, the $P_{R L}$ of the skew is a ratio of the MSE of the station skew when only the gaged record is analyzed $\left(\operatorname{MSE}\left(\hat{G}_{S}\right)\right)$ to the MSE of the station skew when the entire record, including historical and censored data, is analyzed $\left(\operatorname{MSE}\left(\hat{G}_{C}\right)\right)$ :

$$
P_{R L}=\frac{P_{s} \times \operatorname{MSE}\left(\hat{G}_{S}\right)}{\operatorname{MSE}\left(\hat{G}_{C}\right)},
$$

where

$$
\begin{gathered}
P_{R L} \quad \begin{array}{c}
\text { is the pseudo length of the entire record at the } \\
\text { streamgage, in years; }
\end{array} \\
P_{S} \quad \begin{array}{l}
\text { is the number of years with gaged peaks in } \\
\text { the record; }
\end{array} \\
\operatorname{MSE}\left(\hat{G}_{S}\right) \quad \begin{array}{l}
\text { is the estimated MSE of the skew when only } \\
\text { the gaged record is analyzed; and }
\end{array} \\
\operatorname{MSE}\left(\hat{G}_{C}\right) \quad \begin{array}{l}
\text { is the estimated MSE of the skew when the } \\
\text { entire record, including historical and } \\
\text { censored data, is analyzed. }
\end{array}
\end{gathered}
$$

Because the $P_{R L}$ is an estimate, the following conditions must also be met to ensure a valid approximation. The $P_{R L}$ must be nonnegative. If $P_{R L}$ is greater than $P_{H}$ (the length of the historical period), then $P_{R L}$ should be set to equal $P_{H}$. Also, if $P_{R L}$ is less than $P_{S}$, then $P_{R L}$ is set to $P_{S}$. This ensures that the $P_{R L}$ will not be larger than the complete $P_{H}$ or less than $P_{S}$.

As stated in $\mathrm{B} 17 \mathrm{C}$, the station skew is sensitive to extreme events; therefore, accurate estimates of skew require longer periods of record, typically 50 years or greater. However, 50 years of record are not available for most streamgages, and therefore a minimum of 30 to 40 years has been used in recent studies (Eash and others, 2013; Paretti and 
Table 2. Basin characteristics considered for use as explanatory variables in the regional skew analysis.

[GIS, geographic information system; NHDPlus, National Hydrography Dataset Plus; NAD83, North American Datum of 1983; PRISM, Parameter Regression on Independent Slopes Model; NLCD, National Land Cover Database]

\begin{tabular}{|c|c|c|}
\hline Basin characteristic & Units & Source \\
\hline $\begin{array}{l}\text { Drainage area of streamgage basin, delineated by } \\
\text { using GIS }\end{array}$ & Square kilometers & Derived from 30-meter NHDPlus data, http://www.horizon-systems.com/nhdplus/. \\
\hline Latitude of basin centroid & Decimal degrees, NAD83 & $\begin{array}{l}\text { Determined from zonal statistics of grids derived from basin polygons in Esri } \\
\text { ArcGIS, version 10.3.1. }\end{array}$ \\
\hline Longitude of basin centroid & Decimal degrees, NAD83 & $\begin{array}{l}\text { Determined from zonal statistics of grids derived from basin polygons in Esri } \\
\text { ArcGIS, version 10.3.1. }\end{array}$ \\
\hline Mean basin elevation & Meters & $\begin{array}{l}\text { Determined from 10-meter resolution National Elevation Dataset, } \\
\text { https://www.usgs.gov/core-science-systems/national-geospatial-program/ } \\
\text { national-map. }\end{array}$ \\
\hline $\begin{array}{l}\left.\text { Basin compactness ratio (area/perimeter }{ }^{2} \times 100\right) \text {; } \\
\text { higher number indicates more compact shape }\end{array}$ & Unitless & $\begin{array}{l}\text { Calculated in Esri ArcGIS, version 10.3.1, by using drainage area and perimeter of } \\
\text { GIS-delineated basin polygons. }\end{array}$ \\
\hline $\begin{array}{l}\text { Basin-averaged mean annual precipitation for the } \\
30 \text {-year period of } 1971 \text { to } 2000\end{array}$ & Centimeters & $\begin{array}{l}\text { 800-meter PRISM data, Oregon State University, } \\
\text { http://www.prism.oregonstate.edu/. }\end{array}$ \\
\hline Mean basin slope & Percent & $\begin{array}{l}\text { Determined from 100-meter resolution National Elevation Dataset, } \\
\text { https://www.usgs.gov/core-science-systems/national-geospatial-program/ } \\
\text { national-map. }\end{array}$ \\
\hline Basin-averaged soil permeability & Inches per hour & $\begin{array}{l}\text { Wolock (1997, https://water.usgs.gov/GIS/metadata/usgswrd/ } \\
\text { XML/muid.xml) and U.S. Department of Agriculture (2008, } \\
\text { https://websoilsurvey.sc.egov.usda.gov/App/WebSoilSurvey.aspx). }\end{array}$ \\
\hline $\begin{array}{l}\text { Percentage of streamgage basin in forested land- } \\
\text { use categories }\end{array}$ & Percentage of streamgage basin surface area & $\begin{array}{l}2006 \text { NLCD, sum of classes } 41,42 \text {, and } 43 \text {, https://www.mrlc.gov/ } \\
\text { data?f\%5B0\%5D=year\%3A2006. }\end{array}$ \\
\hline Percentage of streamgage basin in open water & Percentage of streamgage basin surface area & 2006 NLCD, class 11, https://www.mrlc.gov/data?f\%5B0\%5D=year\%3A2006. \\
\hline
\end{tabular}


others, 2014; Southard and Veilleux, 2014; Wagner and others, 2016). Thus, after adequate geographic and hydrologic coverage was ensured, streamgages in the dataset that had a $P_{R L}$ less than 36 years were removed from the study. Of the 198 streamgages that remained after removing the 17 streamgages located outside the study area boundary and the 17 redundant streamgages, an additional 15 were removed for having a $P_{R L}$ less than 36 years, leaving 183 streamgages from which a regional skew model was developed (table 1; fig. 2).

\section{Removing the Bias of the At-Site Estimators}

The station skew estimates were unbiased by using the correction factor developed by Tasker and Stedinger (1986) and employed by Reis and others (2005). The unbiased station skew estimated by using the $P_{R L}$ is

$$
\hat{\gamma}_{i}=\left[1+\frac{6}{P_{R L, i}}\right] G_{i}
$$

where

$\hat{\gamma}_{i} \quad$ is the unbiased station skew estimate for site $i$,

$P_{R L, i} \quad$ is the pseudo record length in years for site $i$ as calculated in equations 1 and 2, and

$G_{i} \quad$ is the traditional biased station skew estimator based on the flood-frequency analysis for site $i$.

The variance of the unbiased station skew estimate includes the correction factor developed by Tasker and Stedinger (1986):

$$
\operatorname{Var}\left[\hat{\gamma}_{i}\right]=\left[1+\frac{6}{P_{R L, i}}\right]^{2} \operatorname{Var}\left[G_{i}\right]
$$

where

$\operatorname{Var}\left[G_{i}\right] \quad$ is calculated by using the formula (Griffis and Stedinger, 2009):

$$
\operatorname{Var}(\hat{G})=\left[\frac{6}{P_{R L}}+a\left(P_{R L}\right)\right] \times\left[1+\left(\frac{9}{6}+b\left(P_{R L}\right)\right) \hat{G}^{2}+\left(\frac{15}{48}+c\left(P_{R L}\right)\right) \hat{G}^{4}\right]
$$

where

$$
\begin{gathered}
a\left(P_{R L}\right)=-\frac{17.75}{P_{R L}{ }^{2}}+\frac{50.06}{P_{R L}{ }^{3}}, \\
b\left(P_{R L}\right)=\frac{3.92}{P_{R L}^{0.3}}-\frac{31.10}{P_{R L}^{0.6}}+\frac{34.86}{P_{R L}^{0.9}}, \text { and } \\
c\left(P_{R L}\right)=-\frac{7.31}{P_{R L}^{0.59}}+\frac{45.90}{P_{R L}^{1.18}}-\frac{86.50}{P_{R L}^{1.77}} .
\end{gathered}
$$

For the 183 streamgages in the study area used in the skew analysis, the unbiased station skew ranged from -1.65 to 1.66 in $\log _{10}$ units (table 1; fig. 3). 


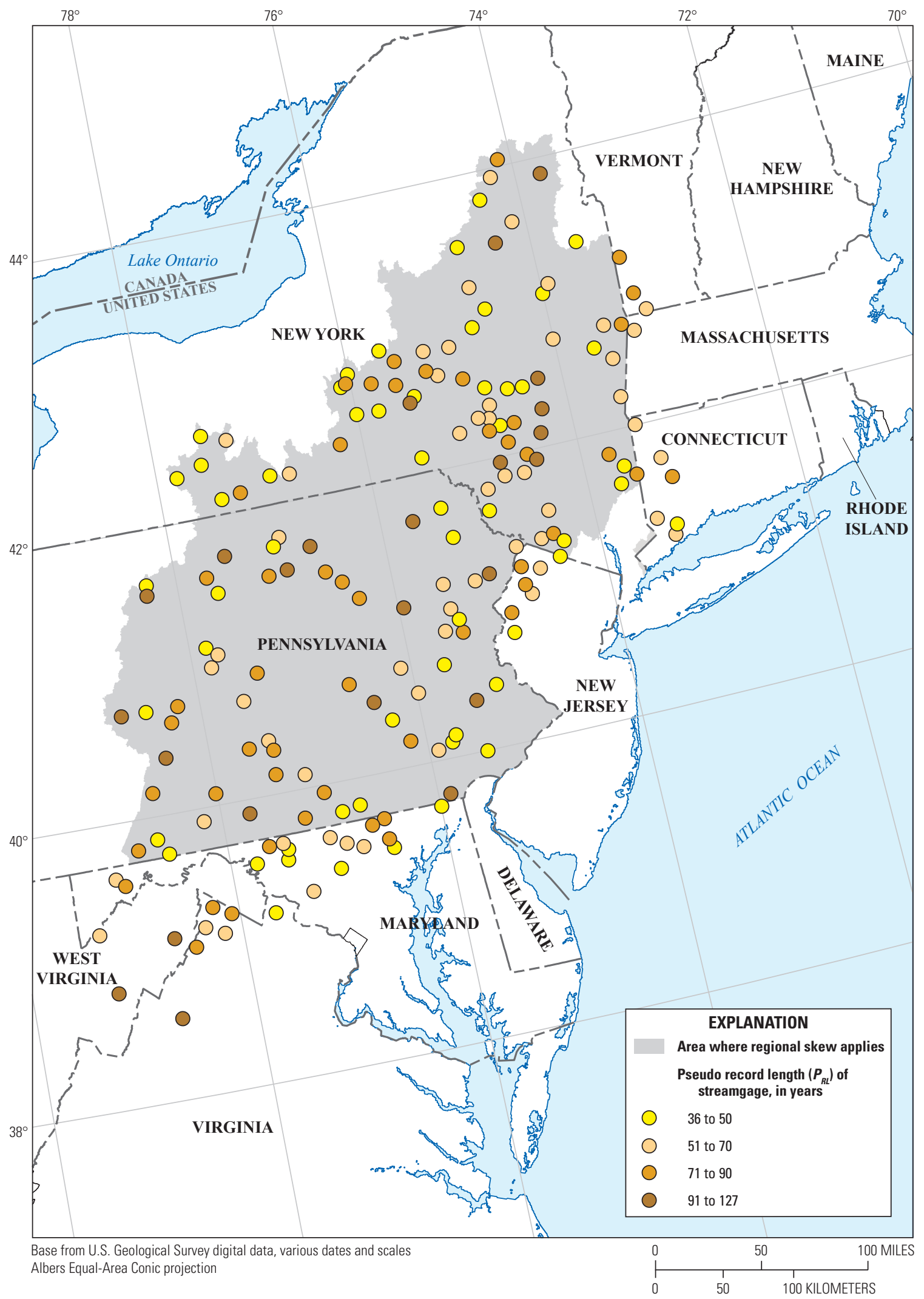

Figure 2. Map showing the pseudo record lengths $\left(P_{R L}\right)$ of streamgages that were used in the regional skew analysis for parts of eastern New York and Pennsylvania. 


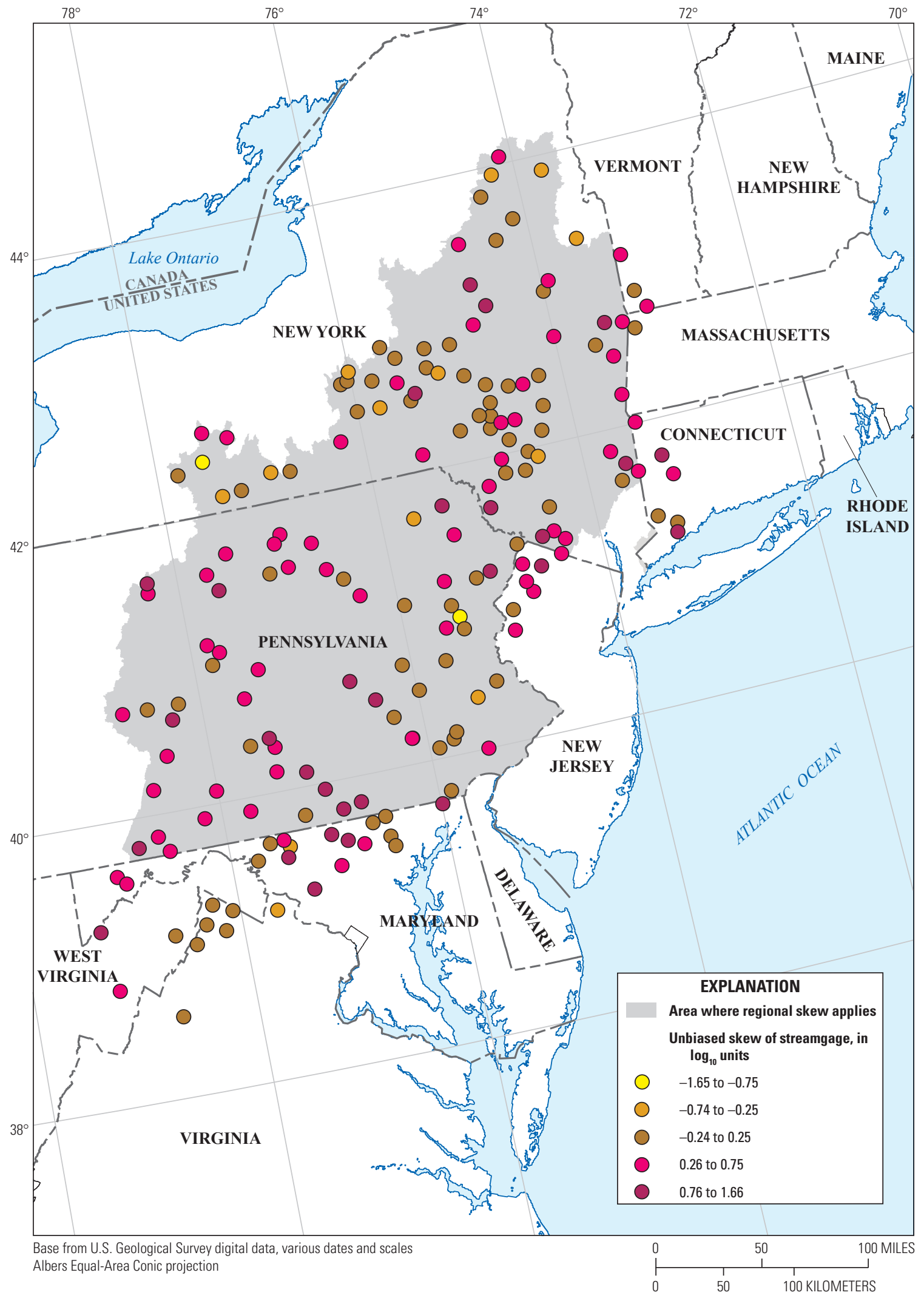

Figure 3. Map showing unbiased station skew of streamgages used in the regional skew analysis for parts of eastern New York and Pennsylvania. 


\section{Estimating the Mean Square Error of the Skew}

There are several possible ways to estimate $\operatorname{MSE}(\hat{G})$. The approach used by EMA (taken from eq. 55 in Cohn and others, 2001) generates a first-order estimate of the $M S E(\hat{G})$, which should perform well when interval data are available. Another option is to use the Griffis and Stedinger (2009) formula in equations 1-7 (the variance is equated to the MSE) by employing either the gaged-record length or the length of the entire historical period (from the beginning year to the ending year of the record); however, this method does not account for censored data and can lead to an inaccurate and underestimated $\operatorname{MSE}(\hat{G})$. This issue was addressed by using the $P_{R L}$ instead of the length of the historical period; the $P_{R L}$ accounts for the effects of the censored data and the number of recorded gaged peaks. Thus, the unbiased $\operatorname{MSE}(\hat{G})$ was used in the regional skewness model because it is more stable and relatively independent of the station skewness estimator (Griffis and Stedinger, 2009). This method also was used in previous regional skew studies (Parrett and others, 2011; Eash and others, 2013; Paretti and others, 2014; Southard and Veilleux, 2014; Wagner and others, 2016).

\section{Developing a Cross-Correlation Model}

A critical step for the B-GLS analysis is the estimation of the cross correlation of the station skew coefficient estimators. Martins and Stedinger (2002) used Monte Carlo experiments to derive a relation between the cross correlation of the skew estimators for two streamgages ( $i$ and $j$ ) as a function of the cross correlation of concurrent annual peak flows $\left(\hat{\rho}_{i j}\right)$ :

$$
\hat{\rho}\left(\hat{\gamma}_{i}, \hat{\gamma}_{j}\right)=\operatorname{Sign}\left(\hat{\rho}_{i j}\right) c f_{i j}\left|\hat{\rho}_{i j}\right|^{k},
$$

where

$\hat{\rho}_{i j} \quad$ is the cross correlation of concurrent annual peak flow for two streamgages,

$k \quad$ is a constant between 2.8 and 3.3 , and

$c f_{i j} \quad$ is a factor that accounts for the sample size difference between the concurrent record lengths of the two streamgages and is defined as follows:

$$
c f_{i j}=C Y_{i j} / \sqrt{\left(P_{R L, i}\right)\left(P_{R L, j}\right)},
$$

where

$$
\begin{array}{rc}
C Y_{i j} & \begin{array}{c}
\text { is the pseudo concurrent record length, and } \\
\text { are the pseudo record lengths corresponding } \\
\text { to streamgages } i \text { and } j, \text { respectively. }
\end{array}
\end{array}
$$

As shown in equation 8 , the pseudo concurrent record length $\left(C Y_{i j}\right)$ is used to compute the cross correlation of station skews. The pseudo concurrent record length depends on the years of common historical records between the two streamgages as well as on the ratio of the pseudo record length to the historical record length $\left(H_{i}\right)$ for each streamgage. Because censored and historical data are used, calculation of the effective concurrent record length is more complex than simply determining the years during which the two streamgages both recorded peaks.

To compute $C Y_{i j}$, the years of historical record in common between the two streamgages are first determined. For the years in common, the following equation that includes the beginning year $\left(Y B_{i j}\right)$ and ending year $\left(Y E_{i j}\right)$ is then used to calculate the concurrent years of record between two streamgages $(i$ and $j)$ :

$$
C Y_{i j}=\left(Y E_{i j}-Y B_{i j}+1\right)\left(\frac{P_{R L, i}}{H_{i}}\right)\left(\frac{P_{R L, j}}{H_{j}}\right) .
$$

A cross-correlation model for the annual peak flows in the study area was developed by using the base-10 logarithms of annual peak flows from 43 streamgages that generated 762 streamgage pairs with at least 80 years of concurrent gaged peaks. As shown in figure $4 A$, a logit model, termed the Fisher $Z$ Transformation $(Z=\log [(1+r) /(1-r)])$, provides a convenient transformation of the sample correlations $\left(r_{i j}\right)$ from the $(-1,+1)$ range to the $(-\infty,+\infty)$ range (Fisher, 1915, 1921). Models relating the cross correlations of the concurrent annual peak flows at two streamgages $\left(\hat{\rho}_{i j}\right)$ to various basin characteristics were considered. The adopted model, which uses only one explanatory variable for estimating the cross correlations of concurrent annual peak flows between two streamgages, is based on the distance, in miles, between basin centroids $\left(D_{i j}\right)$ :

where

$$
\rho_{i j}=\frac{\exp \left(2 Z_{i j}\right)-1}{\exp \left(2 Z_{i j}\right)+1},
$$

$$
Z_{i j}=\exp \left(0.64-0.14\left(\frac{D_{i j}^{0.34}-1}{0.34}\right)\right) .
$$

An OLS regression analysis based on 762 streamgage pairs with at least 80 years of concurrent record indicated that this cross-correlation model is as accurate as having 392 years of concurrent annual peak flows from which to calculate cross correlation. As is standard in an OLS analysis, each station pair in the model was given equal weight. By setting the concurrent-years threshold to 80 , the model allowed the complete range of data in the study to be represented, while 

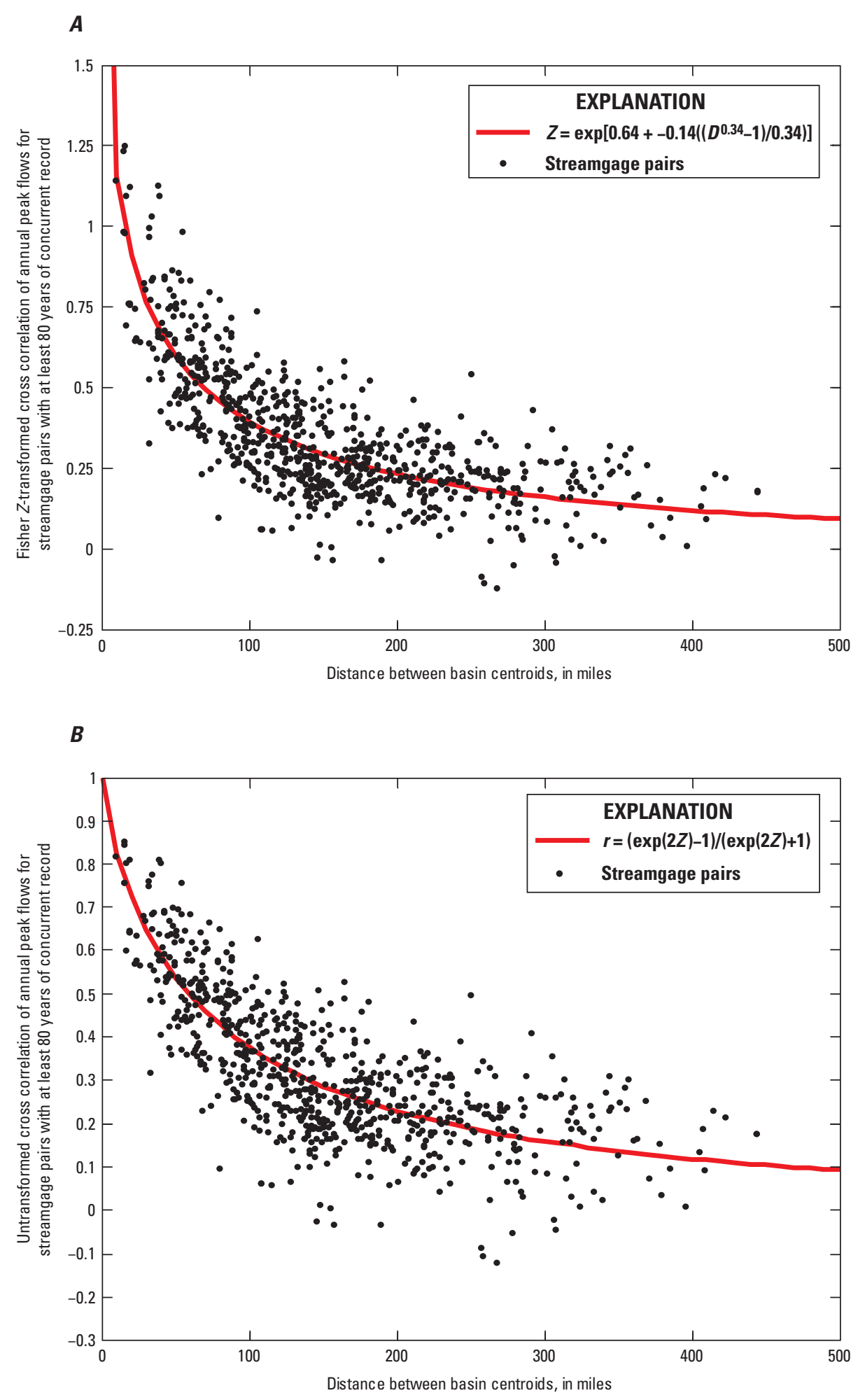

Figure 4. Graphs showing cross correlation of annual peak flows in the study area. $A$, Relation between Fisher Z-transformed cross correlation of logarithms of annual peak flows and the distances between basin centroids for 762 streamgage pairs with at least 80 years of concurrent record. $B$, Relation between untransformed cross correlation of logarithms of annual peak flows and the distances between basin centroids for 762 streamgage pairs with at least 80 years of concurrent record. Abbreviations: $r$, cross correlation of concurrent annual peak flows; $D$, distance between basin centroids, in miles; and $Z$, Fisher Z-transformed cross correlation of annual peak flows. 
also minimizing the influence of station pairs with less accuracy and (or) less data. The fitted OLS regression relation between $Z$ and the distance between basin centroids from the 762 streamgage pairs (fig. $4 A$ ) shows an exponential decline in the cross correlation for streamgages within 100 miles of each other. A similar decline is found in the cross correlation and distance between basin centroids for the untransformed streamgage pairs (fig. 4B). This model was used to estimate cross correlation for concurrent annual peak flows between all streamgage pairs used in the regional skew study.

\section{Regression Analyses}

The B-WLS/B-GLS method for computing a regional skew begins with an OLS analysis to develop a regional skew model that is used to generate an estimate of regional skew for each streamgage (Veilleux, 2011; Veilleux and others, 2011, 2012). The OLS-based regional skew estimate is the basis for computing the variance of the skew for each streamgage. Next, B-WLS is used to generate estimators of the regional skew model parameters. Finally, B-GLS is used to estimate the precision of the B-WLS parameter values and the model error variance and its precision, and to compute various diagnostic statistics.

\section{Ordinary Least Squares Analysis}

The first step in the B-WLS/B-GLS regional skew analysis is to prepare an initial regional skew model by using OLS regression. The OLS regression analysis yields parameters (such as $\hat{\boldsymbol{\beta}}_{\text {OLS }}$ ) and a model that can be used to generate unbiased regional estimates of the skew for all streamgages:

$$
\tilde{y}_{O L S}=\boldsymbol{X} \hat{\boldsymbol{\beta}}_{O L S}
$$

where
$\tilde{y}_{\text {OLS }}$ are the estimated regional skew values,
$\boldsymbol{X}$ is a $(n \times k)$ matrix of basin characteristics,
$\hat{\boldsymbol{\beta}}_{\text {OLS }}$ is a $(k \times 1)$ vector of estimated regression parameters,
$n \quad$ is the number of streamgages, and
$k \quad$ is the number of basin parameters, including a column of ones, to estimate the regression constant.

The estimated regional skew values $\left(\tilde{y}_{O L S}\right)$ are then used to calculate unbiased streamgage regional skew variances by using equation 8 in Griffis and Stedinger (2009). These variances are based on the OLS estimator of the regional skew coefficient instead of the station skew estimator, making the weights in the subsequent steps relatively independent of the station skew estimates.

\section{Weighted Least Squares Analysis}

A B-WLS analysis is used to develop estimators of the regression coefficients for the regional skew model. The B-WLS analysis explicitly reflects variations in record length but intentionally neglects cross correlations, thereby avoiding problems experienced with B-GLS parameter estimators (Veilleux, 2011; Veilleux and others, 2011).

The first step in the B-WLS analysis is to estimate the model error variance $\left(\sigma_{\delta, B-W L S}^{2}\right)$ (Reis and others, 2005). Using a B-WLS approach to estimate the model error variance precludes the pitfall of estimating the model error variance as zero, which can occur when the method-of-moments weighted least-squares regression is used. Although the B-WLS analysis produces an estimate of the distribution of the model error variance, only the mean model error variance estimator is considered. Given the model error variance estimator, a B-WLS analysis is used to generate the weight matrix $(\boldsymbol{W})$ needed to compute estimates of the final regression parameters $\left(\hat{\boldsymbol{\beta}}_{B-W L S}\right)$. To compute $\boldsymbol{W}$, a diagonal covariance matrix $\left[\boldsymbol{\Lambda}_{B-W L S}\left(\sigma_{\delta, B-W L S}^{2}\right)\right]$ is created (eq. 13). The diagonal elements of the covariance matrix are the sum of the estimated model error variance and the variance of the unbiased station skew $\left(\operatorname{Var}\left[\hat{\gamma}_{i}\right]\right)$, which depends upon the record length and the estimate of the previously calculated OLS regional skew $\left(\tilde{y}_{O L S}\right)$. The off-diagonal elements of $\boldsymbol{\Lambda}_{B-W L S}\left(\sigma_{\delta, B-W L S}^{2}\right)$ are zero because cross correlations among sets of streamgage data are not considered in the B-WLS analysis. Thus, the $(n \times n)$ covariance matrix, $\Lambda_{B-W L S}\left(\sigma_{\delta, B-W L S}^{2}\right)$, is given by

$$
\boldsymbol{\Lambda}_{B-W L S}\left(\sigma_{\delta, B-W L S}^{2}\right)=\sigma_{\delta, B-W L S}^{2} \boldsymbol{I}+\operatorname{diag}(\operatorname{Var}[\hat{\gamma}]),
$$


where

$\sigma_{\delta, B-W L S}^{2} \quad$ is the model error variance,

$\boldsymbol{I} \quad$ is an $(n \times n)$ identity matrix,

$n \quad$ is the number of streamgages in the study, and

$\operatorname{diag}(\operatorname{Var}[\hat{\gamma}]) \quad$ is the $(n \times n)$ matrix containing the variance of the unbiased station skew, $\operatorname{Var}\left[\hat{\gamma}_{i}\right]$, on the diagonal and zeros on the off-diagonal.

By using the covariance matrix, the B-WLS weights are calculated as

$$
\boldsymbol{W}=\left[\boldsymbol{X}^{T} \boldsymbol{\Lambda}_{B-W L S}\left(\sigma_{\delta, B-W L S}^{2}\right)^{-1} \boldsymbol{X}\right]^{-1} \boldsymbol{X}^{T} \boldsymbol{\Lambda}_{B-W L S}\left(\sigma_{\delta, B-W L S}^{2}\right)^{-1},
$$

where

$\boldsymbol{W}$ is the $(k \times n)$ matrix of weights,

$\boldsymbol{X} \quad$ is the $(n \times k)$ matrix of explanatory basin parameters,

$\boldsymbol{\Lambda}_{B-W L S}\left(\sigma_{\delta, B-W L S}^{2}\right)$ is the $(n \times n)$ covariance matrix, and

$k$ is the number of basin parameters, including a column of ones, to estimate the regression constant.

These weights are used to compute the final estimates of the regression parameters $(\hat{\boldsymbol{\beta}})$ as

$$
\hat{\boldsymbol{\beta}}_{B-W L S}=\boldsymbol{W} \hat{\gamma}
$$

where

$\hat{\boldsymbol{\beta}}_{B-W L S}$ is the $(k \times 1)$ vector of estimated regression parameters.

\section{Generalized Least Squares Analysis}

After the regression model coefficients $\left(\hat{\boldsymbol{\beta}}_{B-W L S}\right)$ and weights $(\boldsymbol{W})$ have been determined by using a B-WLS analysis, the degrees of precision of the fitted model and the regression coefficients also are estimated by using a B-GLS analysis. Using the B-GLS regression framework for regional skew, Reis and others (2005) developed the posterior probability-density function for model error variance described as

$$
\begin{aligned}
& f\left(\sigma_{\delta, B-G L S}^{2} \mid \hat{\gamma}, \hat{\boldsymbol{\beta}}_{B-W L S}\right) \propto \xi\left(\sigma_{\delta, B-G L S}^{2}\right) \times\left|\boldsymbol{\Lambda}_{B-G L S}\left(\sigma_{\delta, B-G L S}^{2}\right)\right|^{-0.5} \times \\
& \exp \left[-0.5\left(\hat{\gamma}-\boldsymbol{X} \hat{\boldsymbol{\beta}}_{B-W L S}\right)^{T}\left(\boldsymbol{\Lambda}_{B-G L S}\left(\sigma_{\delta, B-G L S}^{2}\right)\right)^{-1}\left(\hat{\gamma}-\boldsymbol{X} \hat{\boldsymbol{\beta}}_{B-W L S}\right)\right]
\end{aligned}
$$

where

$\hat{\gamma} \quad$ represents the skew data, and

$\xi\left(\sigma_{\delta, B-G L S}^{2}\right) \quad$ is the exponential prior for the model error variance defined as

$$
\xi\left(\sigma_{\delta, B-G L S}^{2}\right)=\lambda e^{-\lambda\left(\sigma_{\delta, B-G L S}^{2}\right)}, \sigma_{\delta, B-G L S}^{2}>0 .
$$

The value 10 was adopted for lambda $(\lambda)$ on the basis of a mean model error variance of $1 / 10$. That prior assigns a 63-percent probability to the interval $(0,0.1), 86$-percent probability to the interval $(0,0.2)$, and 95 -percent probability to the interval $(0,0.3)$.

The mean B-GLS model error variance $\left(\sigma_{\delta, B-G L S}^{2}\right)$ can then be used to compute the precision of the regression parameters $\left(\hat{\boldsymbol{\beta}}_{B-W L S}\right)$ that were based on the B-WLS weights $(\boldsymbol{W})$. The B-GLS covariance matrix for the B-WLS estimator $\left(\hat{\boldsymbol{\beta}}_{B-W L S}\right)$ is simply

$$
\Sigma\left(\hat{\boldsymbol{\beta}}_{B-W L S}\right)=\boldsymbol{W} \boldsymbol{\Lambda}_{B-G L S}\left(\sigma_{\delta, B-G L S}^{2}\right) \boldsymbol{W}^{T},
$$


where

$$
\begin{gathered}
\boldsymbol{W} \quad \text { is the }(k \times n) \text { matrix of weights determined by } \\
\text { B-WLS analysis, } \\
\boldsymbol{W}^{T} \quad \text { is the transformation of } \boldsymbol{W} \text {, and } \\
\boldsymbol{\Lambda}_{B-G L S}\left(\sigma_{\delta, B-G L S}^{2}\right) \quad \begin{array}{l}
\text { is the }(n \times n) \text { B-GLS covariance matrix } \\
\text { calculated as }
\end{array}
\end{gathered}
$$$$
\boldsymbol{\Lambda}_{B-G L S}\left(\sigma_{\delta, B-G L S}^{2}\right)=\sigma_{\delta, B-G L S}^{2} \boldsymbol{I}+\Sigma(\hat{\gamma}),
$$

where

$$
\begin{gathered}
\boldsymbol{I} \quad \text { is an }(n \times n) \text { identity matrix, and } \\
\Sigma(\hat{\gamma}) \quad \text { is a full }(n \times n) \text { matrix containing the } \\
\text { sampling variances of the streamflow } \\
\text { record's unbiased skew, } \operatorname{Var}\left[\hat{\gamma}_{i}\right] \text {, and the } \\
\text { covariances of the skew } \hat{\gamma}_{i} .
\end{gathered}
$$

The off-diagonal values of $\boldsymbol{\Sigma}(\hat{\gamma})$ are determined by the cross correlation of concurrent gaged annual peak flows and the $c f$ factor (see eq. 8), which accounts for the size differences between pairs of samples collected at different streamgages and their concurrent record length (Martins and Stedinger, 2002). In the calculation of the $c f$ factor, only the gaged records and historical peaks are considered when determining the ratio of the number of concurrent peak flows at streamgage pairs to the total number of annual peak flows at both streamgages. Thus, any additional information provided by perception thresholds and censored peaks in the EMA analysis is neglected in the calculation of the cross correlation of annual peak flows and the $c f$ factor. Precision metrics include (1) the standard error of the regression parameters $\left[S E\left(\hat{\boldsymbol{\beta}}_{B-W L S}\right)\right] ;(2)$ the model error variance $\left(\sigma_{\delta, B-G L S}^{2}\right)$; (3) pseudo coefficient of determination (pseudo $R_{\delta}^{2}$ ); and (4) the average variance of prediction at a new streamgage not used in the regional model $\left(A V P_{n e w}\right)$.

\section{Results and Discussion}

\section{Final Bayesian Weighted Least Squares/ Bayesian Generalized Least Squares Model}

A constant B-WLS/B-GLS model (having a skew of 0.32 and developed by using data from 183 streamgages with at least 36 years of $P_{R L}$ each) produced the only statistically significant model of skew in the study area (table 3). A constant model does not explain any variability in skew; therefore, the pseudo $R_{\delta}^{2}$, a diagnostic statistic that describes the percentage of the variability in the skew from streamgage to streamgage that is estimated by the model (Gruber and others, 2007; Parrett and others, 2011), is 0 percent. All available basin characteristics were evaluated as possible explanatory variables in the B-WLS/B-GLS regression analysis; however, the addition of any of the available basin characteristics or combinations thereof did not produce a pseudo $R_{\delta}^{2}$ greater than 1 percent, indicating that they did not explain the variation in station skews in the study area. Thus, the addition of basin characteristics as explanatory variables was not warranted because the increase in complexity did not result in a gain in precision.

The posterior mean of the constant model error variance $\left(\sigma_{\delta}^{2}\right)$ is 0.10 . The average sampling error variance $(A S E V)$ of the constant model is 0.0078 , which represents the average error in the regional skew as calculated from the station skew values measured at the streamgages used in the analysis. The average variance of prediction at a new streamgage $\left(A V P_{n e w}\right)$ corresponds to the MSE used in Bulletin 17B (B17B; Interagency Advisory Committee on Water Data, 1982) to describe the precision of the generalized skew map. The constant model has an $A V P_{\text {new }}$ of 0.11 , which corresponds to an effective record length of 68 years. An $A V P_{\text {new }}$ of 0.11 is a marked improvement over the B17B national skew map, whose reported MSE of 0.302 has a corresponding effective record length of only 17 years (Interagency Advisory Committee on Water Data, 1982). Measured by effective record length, the new regional model includes more than three times the information than the B17B map. Appendix 1 provides a graphical assessment of the B-WLS/B-GLS model of regional skew.

\section{Bayesian Weighted Least Squares/Bayesian Generalized Least Squares Regression

\begin{tabular}{|c|c|c|c|c|c|}
\hline Model & Regression constant & $\sigma_{\delta}^{2}$ & ASEV & $A V P_{n e w}$ & $\begin{array}{c}\text { Pseudo } R_{\delta}^{2} \\
\text { (percent) }\end{array}$ \\
\hline Constant & $0.32(0.09)$ & $0.10(0.020)$ & 0.0078 & 0.11 & 0 \\
\hline
\end{tabular} Diagnostics}

To determine whether a regression model is a good representation of the data and which regression parameters, if any, should be included in the model, diagnostic statistics have been developed to evaluate how well a model fits a regional

Table 3. Regional skew model and model fit for parts of eastern New York and Pennsylvania.

[Standard deviations are in parentheses. Terms: $\sigma_{\delta}^{2}$, model error variance; $A S E V$, average sampling error variance; $A V P P_{n e w}$, average variance of prediction at a new streamgage; pseudo $R_{\delta}^{2}$, fraction of the variability of the station skews explained by each model (Gruber and others, 2007)] 
hydrologic dataset (Griffis, 2006; Gruber and Stedinger, 2008). In a regional skew study, potential explanatory variables are statistically evaluated to ensure an accurate prediction of skew while also keeping the model as simple as possible.

A pseudo analysis of variance (pseudo ANOVA) contains regression diagnostics and goodness-of-fit statistics that describe how much of the variation in the observations can be attributed to the regional model, and how much of the variation in the residuals can be attributed to modeling and sampling error (table 4; fig. 5). Determining these quantities is difficult; the modeling errors cannot be resolved because the values of the sampling errors $\left(\eta_{i}\right)$ for each streamgage $(i)$ are not known. However, the total sampling error sum of squares (SS) can be described by its mean value $\left(\sum_{i=1}^{n} \operatorname{Var}\left[\hat{\gamma}_{i}\right]\right)$, where $n$ is the number of equations and where the total variation caused by the model error $(\delta)$ for a model with $k$ parameters has a mean equal to $n \sigma_{\delta}^{2}(k)$. Thus, the residual variation attributed to the sampling error is $\sum_{i=1}^{n} \operatorname{Var}\left[\hat{\gamma}_{i}\right]$, and the residual variation attributed to the model error is $n \sigma_{\delta}^{2}(k)$.

For a model with no explanatory parameters other than the mean (the constant model), the estimated model error variance $\left(\sigma_{\delta}^{2}(0)\right)$ describes all of the variation in $\gamma_{i}=\mu+\delta_{i}$, where $\mu$ is the mean of the estimated station skews. Thus, the total variation resulting from model error $\left(\delta_{i}\right)$ and sampling error $\left(\eta_{i}=\hat{\gamma}_{i}-\gamma_{i}\right)$ in the expected sum of squares should equal $\sigma_{\delta}^{2}(0)+\sum_{i=1}^{n} \operatorname{Var}\left(\hat{\gamma}_{i}\right)$. For a model type other than constant, the expected sum of squares attributed with $k$ parameters equals $n\left[\sigma_{\delta}^{2}(0)-\sigma_{\delta}^{2}(k)\right]$ because the sum of the model error variance $n \sigma_{\delta}^{2}(k)$ and the variance explained by the model must equal $n \sigma_{\delta}^{2}(0)$. This division of the variation in the observations is referred to as a pseudo ANOVA because the contributions of the three sources of error are estimated or constructed rather than determined from the computed residual errors and the observed model predictions, while not accounting for the effect of correlation on the sampling errors.

The error variance ratio $(E V R)$ is a diagnostic statistic used to determine whether a simple OLS regression analysis would suffice, or if a more sophisticated B-WLS or B-GLS analysis would be more appropriate. The EVR is the ratio of the average sampling error variance to the model error variance. Generally, an EVR greater than 0.20 indicates that the sampling error variance is not negligible when compared to the model error variance, suggesting that a B-WLS or B-GLS regression analysis is appropriate. The $E V R$ is calculated as

$$
E V R=\frac{\mathrm{SS}(\text { sampling error })}{\mathrm{SS}(\text { model error })}=\frac{\sum_{i=1}^{n} \operatorname{Var}\left(\hat{\gamma}_{i}\right)}{n \sigma_{\delta}^{2}(k)} .
$$

The constant model has a sampling error variance of 0.0078 (table 3) and an EVR of 1.3 (table 4), indicating that the sampling error variance is not negligible when compared to the model error variance, and that a B-WLS or B-GLS regression analysis was appropriate. Thus, an OLS model that

Table 4. Pseudo analysis of variance (pseudo ANOVA) table for the constant model of regional skew in parts of eastern New York and Pennsylvania.

[Terms: $k$, number of estimated regression parameters not including the constant; $n$, number of streamgages used in regression; $\sigma_{\delta}^{2}(0)$, model error variance of a constant model; $\sigma_{\delta}^{2}(k)$, model error variance of a model with $k$ regression parameters and a constant; NA, not applicable; $\operatorname{Var}\left(\hat{\gamma}_{i}\right)$, variance of the estimated sample skew at site $i ; E V R$, error variance ratio; $M B V^{*}$, misrepresentation of the beta variance; $b_{0}^{B-W L S}$, regression constant from B-WLS analysis; B-GLS, Bayesian generalized least squares; B-WLS, Bayesian weighted least squares; $\boldsymbol{W}^{T}$, the transformation of $\boldsymbol{W} ; \boldsymbol{\Lambda}$, covariance matrix; $\boldsymbol{W}$, the $(k \times n)$ matrix of weights determined by B-WLS analysis; $\boldsymbol{W}_{i}=\frac{1}{\sqrt{\Lambda_{i i}}}$; pseudo $R_{\delta}^{2}$, fraction of variability in the true skews explained by each model (Gruber and others, 2007);

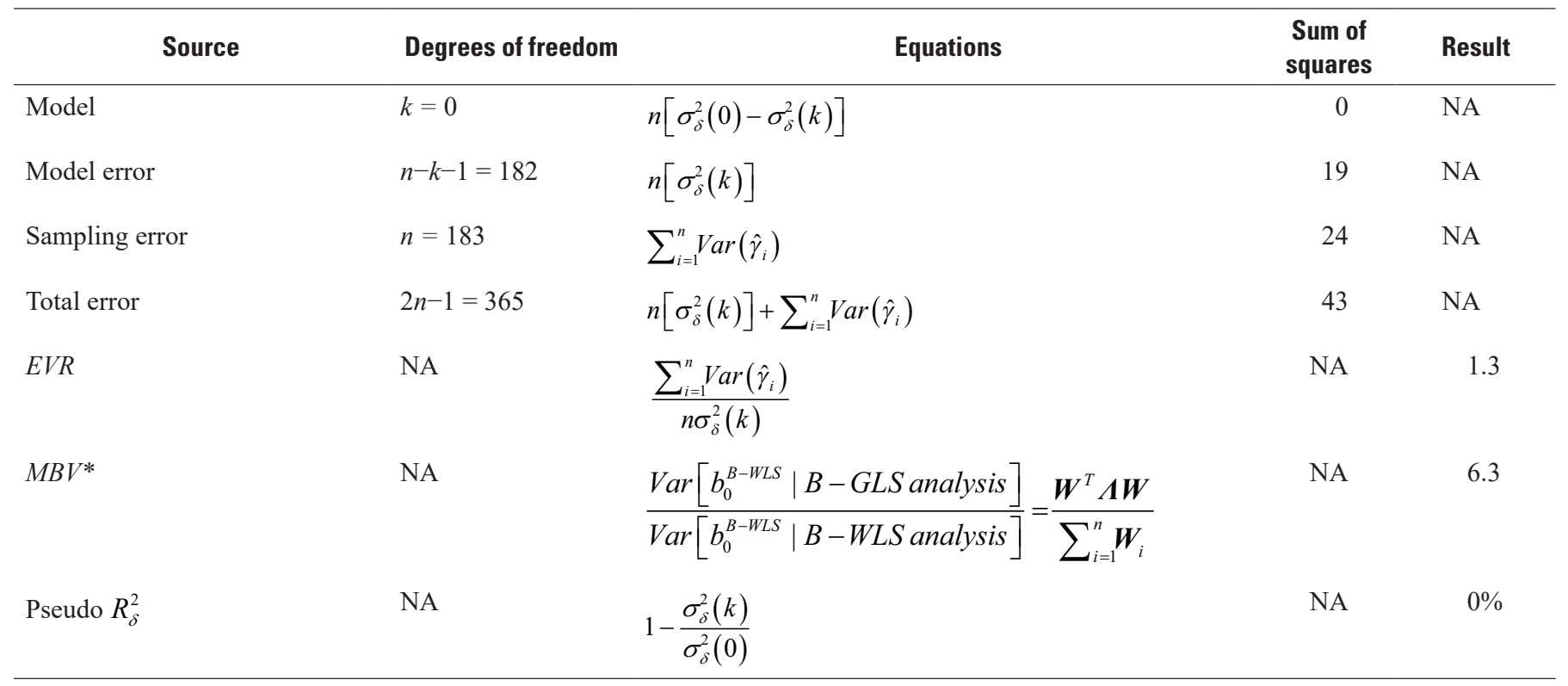




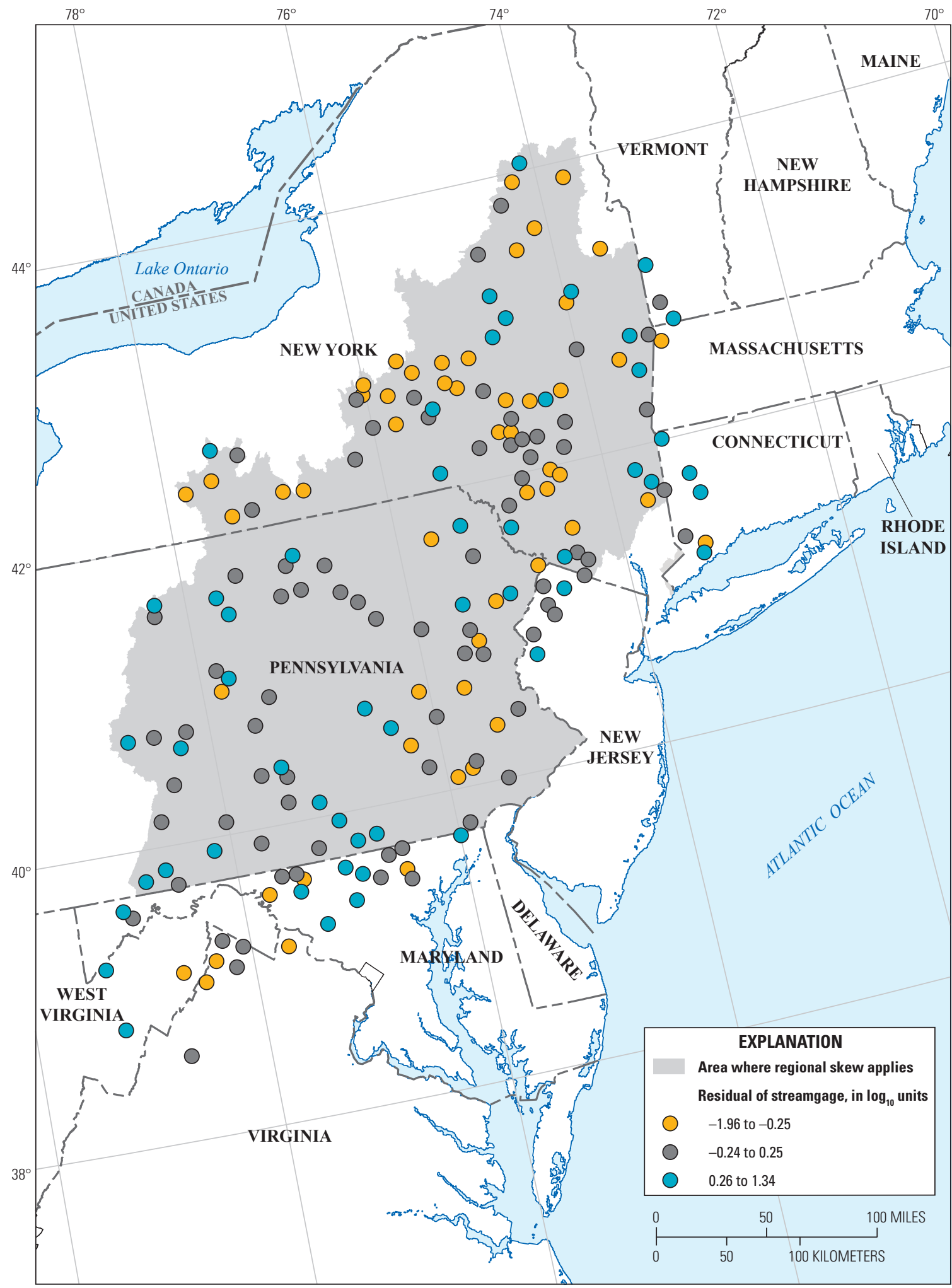

Base from U.S. Geological Survey digital data, various dates and scales

Albers Equal-Area Conic projection

Figure 5. Map showing residuals from constant model of skew for 183 streamgages that were used in the regional skew analysis for parts of eastern New York and Pennsylvania. 
neglects sampling error in the station skew would not provide a statistically reliable analysis of the data. Given the diagnostic statistics and the range of record lengths among streamgages, a B-WLS or B-GLS analysis was warranted to evaluate the final precision of the model.

The misrepresentation of the beta variance $\left(M B V^{*}\right)$ diagnostic statistic is used to determine whether a $\mathrm{B}-\mathrm{WLS}$ regression is sufficient, or if a B-GLS regression is more appropriate to determine the precision of the estimated regression parameters (Griffis, 2006; Veilleux, 2011). The $M B V^{*}$ describes the error produced by a B-WLS regression analysis in its evaluation of the precision of $b_{0}^{B-W L S}$, which is the estimator of the constant $\beta_{0}^{B-W L S}$, because the covariance among the estimated station skews $\left(\hat{\gamma}_{i}\right)$ generally has its greatest effect on the precision of the constant term (Stedinger and Tasker, 1985). If the $M B V^{*}$ is substantially greater than 1, then a B-GLS error analysis should be employed; conversely, if the $M B V^{*}$ is not substantially greater than 1, a $\mathrm{B}-\mathrm{WLS}$ analysis is sufficient. The $M B V^{*}$ is calculated as

$$
M B V^{*}=\frac{\operatorname{Var}\left[b_{0}^{B-W L S} \mid B-G L S \text { analysis }\right]}{\operatorname{Var}\left[b_{0}^{B-W L S} \mid B-W L S \text { analysis }\right]}=\frac{\boldsymbol{W}^{T} \boldsymbol{\Lambda} \boldsymbol{W}}{\sum_{i=1}^{n} \boldsymbol{W}_{i}},
$$

where

$$
\boldsymbol{W}_{i}=\frac{1}{\sqrt{\boldsymbol{\Lambda}_{i i}}}
$$

The $M B V^{*}$ is equal to 6.3 for the constant model (table 4), indicating that the cross correlation among the skew estimators has an effect on the precision with which the regional skew can be estimated. If a B-WLS precision analysis were used for the estimated constant in the model, the variance would be underestimated by a factor of 6.3. Thus, a B-WLS analysis alone would misrepresent the variance of the constant in the skew model. Moreover, a B-WLS model would underestimate the variance of prediction, given that the sampling error in the constant term in both models were sufficiently large to make an appreciable contribution to the average variance of prediction.

\section{Leverage and Influence}

Diagnostic statistics for leverage and influence can be used to identify atypical observations and to address lack-of-fit when skew coefficients are estimated. The leverage statistics identify those streamgages in the analysis for which the observed streamflow values have a large impact on the fitted (or predicted) values (Hoaglin and Welsch, 1978). Generally, leverage statistics can determine whether an observation or explanatory variable is unusual and thus likely to have a large effect on the estimated regression coefficients and predictions. Unlike leverage, which highlights points that have the ability or potential to affect the fit of the regression, influence (measured using Cook's distance, or "Cook's D") attempts to describe those points that have an unusual effect on the regression analysis (Belsley and others, 1980; Cook and Weisberg, 1982; Tasker and Stedinger, 1989). An influential observation is one with an unusually large residual that has a disproportionate effect on the fitted regression relations.

Influential observations often have high leverage. If $p$ is the number of estimated regression coefficients ( $p=1$ for a constant model), and $n$ is the sample size (or number of streamgages in the study), then leverage values have a mean of $p / n$, and values greater than $2 p / n$ are generally considered large. Influence values greater than $4 / n$ are typically considered large (Veilleux, 2011; Veilleux and others, 2011).

For the constant model of skew in the study area, influence greater than $0.022(p / n=4 / 183)$ and leverage greater than $0.011[(2 \times 1) / 183]$ were considered high. No sites in the study area exhibited high leverage; therefore, the differences in the leverage values for the constant model reflect the variation in record lengths among sites. Twelve streamgages in the study area exhibited high influence, and thus had an unusual effect on the fitted regression (table 5). These streamgages also had 12 of the largest residuals (in magnitude) among the 183 streamgages used in the B-WLS/B-GLS analysis. 
Table 5. Streamgages with high influence on the constant model of regional skew.

[High influence is defined as Cook's distance (Cook's D) values greater than $4 / n$ (or 4/183=0.022). Each of the 183 sites in the regional skew study was assigned a value from 1 to 183 signifying its relative rank, where a rank of 1 corresponds to the largest positive value in each category. The table is sorted from the largest to the smallest Cook's D values. Abbreviations: USGS, U.S. Geological Survey; ERL, effective record length; MSE, mean squared error; PA, Pennsylvania; NY, New York; MD, Maryland]

\begin{tabular}{|c|c|c|c|c|c|c|c|c|c|c|c|c|}
\hline \multirow[t]{2}{*}{ Index number } & \multirow{2}{*}{$\begin{array}{c}\text { USGS } \\
\text { streamgage } \\
\text { number }\end{array}$} & \multirow{2}{*}{$\begin{array}{c}\text { State in } \\
\text { which } \\
\text { streamgage is } \\
\text { located }\end{array}$} & \multirow[t]{2}{*}{ Cook's D } & \multirow[t]{2}{*}{ Leverage } & \multicolumn{2}{|c|}{ Pseudo ERL (years) } & \multicolumn{2}{|c|}{ Unbiased at-site skew } & \multicolumn{2}{|c|}{$\begin{array}{l}\text { Unbiased MSE } \\
\text { (at-site skew) }\end{array}$} & \multicolumn{2}{|c|}{ Residual } \\
\hline & & & & & Value & Rank & Value & Rank & Value & Rank & Value & Rank \\
\hline 212 & 01574000 & PA & 0.079 & 0.007 & 85 & 34 & 1.7 & 1 & 0.09 & 147 & 1.3 & 3 \\
\hline 211 & 01573000 & PA & 0.050 & 0.007 & 95 & 20 & 1.3 & 4 & 0.08 & 163 & 1.0 & 6 \\
\hline 161 & 01449360 & PA & 0.050 & 0.005 & 47 & 134 & -1.5 & 182 & 0.17 & 50 & -1.8 & 2 \\
\hline 170 & 01473000 & PA & 0.046 & 0.007 & 99 & 15 & -0.6 & 180 & 0.07 & 169 & -0.92 & 11 \\
\hline 78 & 01358500 & NY & 0.031 & 0.005 & 59 & 98 & 1.5 & 2 & 0.13 & 83 & 1.2 & 4 \\
\hline 144 & 01521596 & NY & 0.030 & 0.004 & 36 & 175 & -1.6 & 183 & 0.22 & 9 & -2.0 & 1 \\
\hline 197 & 01555500 & PA & 0.029 & 0.007 & 84 & 38 & 1.1 & 10 & 0.09 & 142 & 0.82 & 14 \\
\hline 157 & 01439500 & $\mathrm{PA}$ & 0.029 & 0.007 & 105 & 5 & 1.0 & 16 & 0.07 & 179 & 0.70 & 21 \\
\hline 33 & 01595500 & MD & 0.029 & 0.006 & 63 & 90 & 1.4 & 3 & 0.12 & 93 & 1.1 & 5 \\
\hline 28 & 01586000 & MD & 0.028 & 0.006 & 68 & 80 & 1.3 & 5 & 0.11 & 103 & 1.0 & 8 \\
\hline 177 & 01534000 & PA & 0.023 & 0.007 & 100 & 10 & -0.3 & 174 & 0.07 & 174 & -0.65 & 28 \\
\hline 48 & 01643500 & $\mathrm{MD}$ & 0.022 & 0.006 & 65 & 84 & 1.2 & 8 & 0.12 & 97 & 0.89 & 12 \\
\hline
\end{tabular}




\section{Summary}

Bulletin 17C (B17C) guidelines recommend fitting the log-Pearson Type III (LP-III) distribution to a series of annual peak flows at a station by using the method of moments. The LP-III distribution is described by three moments: the mean, the standard deviation, and the skewness coefficient. The third moment, the skewness coefficient (hereinafter referred to as "skew"), is a measure of the asymmetry of the distribution or, in other words, the thickness of the tails of the distribution. In flood-frequency analysis, the skew is important because the magnitude of annual exceedance probability (AEP) flows for a streamgage estimated by using the LP-III distribution are affected by the skew of the annual peak flows (hereinafter referred to as "station skew"); interest is focused on the righthand tail of the distribution, which represents annual peak flows corresponding to small AEPs and the larger flood flows. For streamgages having modest record lengths, the skew is sensitive to extreme events, such as large floods, as they cause a sample to be highly asymmetrical, or skewed. Thus, $\mathrm{B} 17 \mathrm{C}$ recommends using a weighted-average skew computed from the station skew for a given streamgage and a regional skew. These choices reduce the sensitivity of the station skew to extreme events, particularly for streamgages with short record lengths.

An estimate of regional skew is generated for a study area that includes part of the Mid-Atlantic region (hydrologic units 0202, 0204, 0205, 0206, and 0207) and the Connecticut Coastal region (hydrologic unit 0110) located in the States of Connecticut, Maryland, Massachusetts, New Jersey, New York, Pennsylvania, Vermont, Virginia, and West Virginia. The study area encompasses 49,817 square miles and spans approximately 300 miles from north to south (from northern New York to the southern border of Pennsylvania) and approximately 200 miles from east to west (from west-central Pennsylvania to the eastern border of New York).

Candidate streamgages in the study area were selected by the U.S. Geological Survey (USGS) in New York and Pennsylvania. Only streamgage records unaffected by extensive regulation, diversion, urbanization, or channelization, and that had approximately 25 or more gaged peaks were considered.

As recommended in $\mathrm{B} 17 \mathrm{C}$, the flood frequency for each candidate streamgage was determined by employing the expected moments algorithm (EMA), which extends the method of moments so that it can accommodate interval, censored, and historical/paleo data, as well as use the multiple Grubbs-Beck test (MGBT) to identify potentially influential low floods (PILFs) in the data series.

A total of 232 candidate streamgages were initially considered for use in the skew analysis; after screening for redundancy and sufficient pseudo record length $\left(P_{R L}\right)$, 183 streamgages were selected. The Bayesian weighted least squares/Bayesian generalized least squares (B-WLS/B-GLS) regression method was used to develop a regional skew model for the study area that would incorporate possible explanatory variables (basin characteristics) to explain the variation in skew in the study area. Basin characteristics for candidate streamgages were obtained from the USGS Geospatial Attributes of Gages for Evaluating Streamflow, Version II (GAGES-II) database or were generated by using the ArcHydro package in Esri ArcGIS version 10.3.1. Ten basin characteristics were considered as possible explanatory variables in the B-WLS/B-GLS regression analysis; however, none produced a pseudo coefficient of determination greater than 1 percent, indicating that they did not explain the variation in station skews in the study area. Therefore, a constant skew model was selected. The constant model has a regional skew coefficient of 0.32 and an average variance of prediction at a new streamgage $\left(A V P_{n e w}\right)$ of 0.11 , which corresponds to the mean square error (MSE). An $A V P_{n e w}$ of 0.11 corresponds to an effective record length of 68 years, which is a marked improvement over the Bulletin 17B (B17B) national skew map, whose reported MSE of 0.302 has a corresponding effective record length of only 17 years. Measured by effective record length, the new regional model provides more than three times the amount of information provided by the B17B map.

\section{Acknowledgments}

The authors would like to acknowledge Doug Burns and Gary Wall in the U.S. Geological Survey (USGS) New York Water Science Center and Mark Roland in the USGS Pennsylvania Water Science Center for selecting streamgages from their respective States and parts of adjacent States for use in the regional skew analysis and for conducting floodfrequency analyses for those streamgages. The authors would also like to acknowledge Chris Sanoki and Danny Morel in the USGS Upper Midwest Water Science Center for generating basin characteristics for streamgages that were not in the GAGES-II database.

\section{References Cited}

Belsley, D.A., Kuh, E., and Welsch, R.E., 1980, Regression diagnostics - Identifying influential data and sources of collinearity: Hoboken, N.J., John Wiley \& Sons, Inc., 300 p. [Also available at https://doi.org/10.1002/0471725153.]

Cohn, T.A., Lane, W.L., and Baier, W.G., 1997, An algorithm for computing moments-based flood quantile estimates when historical flood information is available: Water Resources Research, v. 33, no. 9, p. 2089-2096, accessed October 1, 2019, at https://doi.org/10.1029/97WR01640. 
Cohn, T.A., Lane, W.L., and Stedinger, J.R., 2001, Confidence intervals for expected moments algorithm flood quantile estimates: Water Resources Research, v. 37, no. 6, p. 1695-1706. [Also available at https://doi.org/10.1029/2001WR900016.]

Cook, R.D., and Weisberg, S., 1982, Residuals and influence in regression: New York, N.Y., Chapman and Hall, 230 p.

Curran, J.H., Barth, N.A., Veilleux, A.G., and Ourso, R.T., 2016, Estimating flood magnitude and frequency at gaged and ungaged sites on streams in Alaska and conterminous basins in Canada, based on data through water year 2012: U.S. Geological Survey Scientific Investigations Report 2016-5024, 47 p., accessed October 1, 2017, at https://doi.org/10.3133/sir20165024.

Eash, D.A., Barnes, K.K., and Veilleux, A.G., 2013, Methods for estimating annual exceedance-probability discharges for streams in Iowa, based on data through water year 2010: U.S. Geological Survey Scientific Investigations Report 2013-5086, 63 p. with appendix.

England, J.F., Jr., Cohn, T.A., Faber, B.A., Stedinger, J.R., Thomas, W.O., Jr., Veilleux, A.G., Kiang, J.E., and Mason, R.R., Jr., 2018, Guidelines for determining flood flow frequency-Bulletin 17C (ver. 1.1, May 2019): U.S. Geological Survey Techniques and Methods, book 4, chap. B5, 148 p. [Also available at https://doi.org/ 10.3133/tm4B5.]

Environmental Systems Research Institute [Esri], 2009, ArcGIS desktop help, accessed November 23, 2015, at https://desktop.arcgis.com/en/desktop/.

Falcone, J.A., 2011, GAGES-II-Geospatial attributes of gages for evaluating streamflow: U.S. Geological Survey dataset, accessed October 1, 2015, at https://pubs.er.usgs.gov/ publication/70046617.

Fenneman, N.M., 1938, Physiography of the Eastern United States (1st ed.): New York, McGraw-Hill Book Co., 714 p.

Fisher, R.A., 1915, Frequency distribution of the values of the correlation coefficient in samples of an indefinitely large population: Biometrika, v. 10, no. 4, p. 507-521. [Also available at https://www.jstor.org/stable/2331838.]

Fisher, R.A., 1921, On the "probable error" of a coefficient of correlation deduced from a small sample: Metron, v. 1, p. 3-32.

Griffis, V.W., 2006, Flood-frequency analysis-Bulletin 17, regional information, and climate change: Ithaca, N.Y., Cornell University, Ph.D. dissertation, 241 p.

Griffis, V.W., and Stedinger, J.R., 2007, Evolution of flood frequency analysis with Bulletin 17: Journal of Hydrologic Engineering, v. 12, no. 3, p. 283-297, accessed October 1, 2019, at https://doi.org/10.1061/(ASCE)10840699(2007)12:3(283).
Griffis, V.W., and Stedinger, J.R., 2009, Log-Pearson type 3 distribution and its application in flood frequency analysis, III-Sample skew and weighted skew estimators: Journal of Hydrology (Amsterdam), v. 14, no. 2, p. 121-130.

Gruber, A.M., Reis, D.S., Jr., and Stedinger, J.R., 2007, Models of regional skew based on Bayesian GLS regression, in Kabbes, K.C., ed., Proceedings of the 2007 World Environmental and Water Resources Congress-Restoring our natural habitat, Tampa, Fla., May 15-18, 2007: Reston, Va., American Society of Civil Engineers, 10 p., accessed October 3, 2019, at https://doi.org/10.1061/40927(243)400.

Gruber, A.M., and Stedinger, J.R., 2008, Models of LP3 regional skew, data selection, and Bayesian GLS regression, in Babcock, R.W., and Walton, R., eds., World Environmental and Water Resources Congress 2008Ahupua'a-Proceedings of the congress, Honolulu, Hawai'i, May 12-16, 2008: Reston, Va., American Society of Civil Engineers, p. 5575-5584. [Also available at https://doi.org/ 10.1061/40976(316)563.]

Hoaglin, D.C., and Welsch, R.E., 1978, The hat matrix in regression and ANOVA: The American Statistician, v. 32, no. 1, p. $17-22$.

Homer, C.G., Dewitz, J.A., Yang, L., Jin, S., Danielson, P., Xian, G., Coulston, J., Herold, N.D., Wickham, J.D., and Megown, K., 2015, Completion of the 2011 National Land Cover Database for the conterminous United StatesRepresenting a decade of land cover change information: Photogrammetric Engineering and Remote Sensing, v. 81 , no. 5 , p. $345-354$, accessed October 12,2018 , at https://cfpub.epa.gov/si/si_public_record_report.cfm?Lab= NERL\&dirEntryId=309950.

Interagency Advisory Committee on Water Data, 1982, Guidelines for determining flood flow frequency-Bulletin 17B (revised and corrected): Washington, D.C., Hydrologic Subcommittee, $28 \mathrm{p}$.

Martins, E.S., and Stedinger, J.R., 2002, Cross correlations among estimators of shape: Water Resources Research, v. 38, no. 11, p. 34-1 to 34-7. [Also available at https://doi.org/10.1029/2002WR001589.]

Mastin, M.C., Konrad, C.P., Veilleux, A.G., and Tecca, A.E., 2016, Magnitude, frequency, and trends of floods at gaged and ungaged sites in Washington, based on data through water year 2014 (ver. 1.2, November 2017): U.S. Geological Survey Scientific Investigations Report 2016-5118, 70 p., accessed October 1, 2017, at https://doi.org/10.3133/ sir20165118. 
Olson, S.A., 2014, Estimation of flood discharges at selected annual exceedance probabilities for unregulated, rural streams in Vermont, with a section on Vermont regional skew regression, by Veilleux, A.G.: U.S. Geological Survey Scientific Investigations Report 2014-5078, 27 p. plus appendixes, accessed October 1, 2015, at https://doi.org/ $10.3133 / \operatorname{sir} 20145078$.

Paretti, N.V., Kennedy, J.R., Turney, L.A., and Veilleux, A.G., 2014, Methods for estimating magnitude and frequency of floods in Arizona, developed with unregulated and rural peak-flow data through water year 2010: U.S. Geological Survey Scientific Investigations Report 2014-5211, 61 p., accessed October 1, 2015, at https://doi.org/10.3133/ $\operatorname{sir} 20145211$.

Parrett, C., Veilleux, A.G., Stedinger, J.R., Barth, N.A., Knifong, D.L., and Ferris, J.C., 2011, Regional skew for California, and flood frequency for selected sites in the Sacramento-San Joaquin River Basin, based on data through water year 2006: U.S. Geological Survey Scientific Investigations Report 2010-5260, 94 p. [Also available at https://doi.org/10.3133/sir20105260.]

Reis, D.S., Jr., Stedinger, J.R., and Martins, E.S., 2005, Bayesian generalized least squares regression with application to the log Pearson type 3 regional skew estimation: Water Resources Research, v. 41, no. 10, W10419, 14 p. [Also available at https://doi.org/10.1029/2004WR003445.]

Southard, R.E., and Veilleux, A.G., 2014, Methods for estimating annual exceedance-probability discharges and largest recorded floods for unregulated streams in rural Missouri: U.S. Geological Survey Scientific Investigations Report 2014-5165, 39 p. [Also available at https://doi.org/10.3133/ sir20145165.]

Stedinger, J.R., and Cohn, T.A., 1986, Flood frequency analysis with historical and paleoflood information: Water Resources Research, v. 22, no. 5, p. 785-793. [Also available at https://doi.org/10.1029/WR022i005p00785.]

Stedinger, J.R., and Tasker, G.D., 1985, Regional hydrologic analysis, 1. Ordinary, weighted, and generalized least squares compared: Water Resources Research, v. 21, no. 9, p. 1421-1432. [Also available at https://doi.org/10.1029/ WR021i009p01421.]

Tasker, G.D., and Stedinger, J.R., 1986, Regional skew with weighted LS regression: Journal of Water Resources Planning and Management, v. 112, no. 2, p. 225-237. [Also available at https://doi.org/10.1061/(ASCE)07339496(1986)112:2(225).]

Tasker, G.D., and Stedinger, J.R., 1989, An operational GLS model for hydrologic regression: Journal of Hydrology (Amsterdam), v. 111, nos. 1-4, p. 361-375. [Also available at https://doi.org/10.1016/0022-1694(89)90268-0.]
U.S. Department of Agriculture, 2008, U.S. general soil map (STATSGO): U.S. Department of Agriculture, Natural Resources Conservation Service database, accessed October 2015 at https://www.nrcs.usda.gov/wps/portal/nrcs/ main/soils/survey/.

U.S. Geological Survey, 2018, USGS water data for the Nation: U.S. Geological Survey National Water Information System database, accessed October 1, 2018, at https://doi.org/ 10.5066/F7P55KJN. [Peak streamflow information directly accessible at https://nwis.waterdata.usgs.gov/nwis/peak.]

U.S. Geological Survey, 2019, The National Map downloader: U.S. Geological Survey web page, accessed January 2019 at https://apps.nationalmap.gov/downloader/\#/.

Veilleux, A.G., 2009, Bayesian GLS regression for regionalization of hydrologic statistics, floods and Bulletin 17 skew: Ithaca, N.Y., Cornell University, M.S. thesis, 155 p.

Veilleux, A.G., 2011, Bayesian GLS regression, leverage, and influence for regionalization of hydrologic statistics: Ithaca, N.Y., Cornell University, Ph.D. dissertation, 184 p.

Veilleux, A.G., Cohn, T.A., Flynn, K.M., Mason, R.R., and Hummel, P.R., 2014, Estimating magnitude and frequency of floods using the PeakFQ 7.0 program: U.S. Geological Survey Fact Sheet 2013-3108, 2 p., accessed October 1, 2015, at https://doi.org/10.3133/fs20133108.

Veilleux, A.G., Stedinger, J.R., and Eash, D.A., 2012, Bayesian WLS/GLS regression for regional skewness analysis for regions with large crest stage gage networks, in Loucks, E.D., ed., Proceedings of the World Environmental and Water Resources Congress 2012 - Crossing boundaries, Albuquerque, N. Mex., May 20-24, 2012: Reston, Va., American Society of Civil Engineers, p. 2253-2263.

Veilleux, A.G., Stedinger, J.R., and Lamontagne, J.R., 2011, Bayesian WLS/GLS regression for regional skewness analysis for regions with large cross-correlations among flood flows, in Beighley, R.E., II, and Killgore, M.W., eds., Proceedings of the World Environmental and Water Resources Congress 2011-Bearing knowledge for sustainability, Palm Springs, Calif., May 22-26, 2011: Reston, Va., American Society of Civil Engineers, p. 3103-3123.

Veilleux, A.G., and Wagner, D.M., 2019, Methods for estimating regional skewness of annual peak flows in parts of the Great Lakes and Ohio River Basins, based on data through water year 2013: U.S. Geological Survey Scientific Investigations Report 2019-5105, 26 p., accessed February 1, 2020, at https://doi.org/10.3133/sir20195105. 
Wagner, D.M., Krieger, J.D., and Veilleux, A.G., 2016, Methods for estimating annual exceedance probability discharges for streams in Arkansas, based on data through water year 2013: U.S. Geological Survey Scientific Investigations Report 2016-5081, 136 p., accessed August 5, 2016, at https://doi.org/10.3133/sir20165081.

Wagner, D.M., and Veilleux, A.G., 2021, Regional flood skew for parts of the mid-Atlantic region (hydrologic unit 02) in eastern New York and Pennsylvania: U.S. Geological Survey data release, accessed February 1, 2021, at https://doi.org/10.5066/P9PGAL0D.
Wolock, D.M., 1997, STATSGO soil characteristics for the conterminous United States: U.S. Geological Survey Open-File Report 97-656, accessed October 7, 2019, at https://doi.org/10.3133/ofr97656. 

Table 1. Streamgages that were considered for use in the regional skew analysis for parts of eastern New York and Pennsylvania. 
Table 1. Streamgages that were considered for use in the regional skew analysis for parts of eastern New York and Pennsylvania.

[Locality abbreviations: CT, Connecticut; MA, Massachusetts; MD, Maryland; NJ, New Jersey; NY, New York; PA, Pennsylvania; VA, Virginia; VT, Vermont; WV, West Virginia. Other abbreviations: USGS, U.S. Geological Survey; EMA, expected moments algorithm; MSE, mean-square error; NA, not applicable because the streamgage was not used in the regional skew analysis; no-O, streamgage not used in regional skew analysis due to 4-digit hydrologic unit code outside the study area; no-P, streamgage not used in regional skew analysis due to Psuedo record length less than 36 years; no-R, streamgage not used in regional skew analysis due to redundancy]

\begin{tabular}{|c|c|c|c|c|c|c|c|c|}
\hline \multirow{2}{*}{$\begin{array}{l}\text { Regional } \\
\text { skew index } \\
\text { number }\end{array}$} & \multirow{2}{*}{$\begin{array}{c}\text { USGS } \\
\text { streamgage } \\
\text { number }\end{array}$} & \multirow{2}{*}{$\begin{array}{l}\text { Hydrologic } \\
\text { Unit Code } \\
\text { (4-digit) }\end{array}$} & \multirow{2}{*}{$\begin{array}{l}\text { State where } \\
\text { streamgage is } \\
\text { located }\end{array}$} & \multirow{2}{*}{$\begin{array}{l}\text { Pseudo } \\
\text { record } \\
\text { length } \\
\left(P_{R L^{\prime}} \text { years }\right)\end{array}$} & \multirow{2}{*}{$\begin{array}{l}\text { Unbiased } \\
\text { station skew } \\
\text { (log units) }\end{array}$} & \multicolumn{2}{|c|}{ EMA analysis } & \multirow{2}{*}{$\begin{array}{l}\text { Used in } \\
\text { regional } \\
\text { skew } \\
\text { model }\end{array}$} \\
\hline & & & & & & $\begin{array}{l}\text { Skew coef- } \\
\text { ficient (log } \\
\text { units) }\end{array}$ & $\begin{array}{l}\text { MSE of } \\
\text { skew (log } \\
\text { units) }\end{array}$ & \\
\hline 1 & 01184100 & 0108 & $\mathrm{CT}$ & 54 & NA & 0.167 & 0.1063 & no-O \\
\hline 2 & 01187300 & 0108 & $\mathrm{CT}$ & 75 & NA & 0.099 & 0.0754 & no-O \\
\hline 3 & 01187800 & 0108 & $\mathrm{CT}$ & 65 & NA & 0.894 & 0.1542 & no-O \\
\hline 4 & 01188000 & 0108 & $\mathrm{CT}$ & 82 & NA & 0.001 & 0.0647 & no-O \\
\hline 5 & 01192883 & 0108 & $\mathrm{CT}$ & 33 & NA & -0.26 & 0.1732 & no-O \\
\hline 6 & 01199050 & 0110 & $\mathrm{CT}$ & 54 & 0.61 & 0.548 & 0.1331 & Yes \\
\hline 7 & 01200000 & 0110 & $\mathrm{CT}$ & 81 & 0.42 & 0.389 & 0.0871 & Yes \\
\hline 8 & 01203000 & 0110 & $\mathrm{CT}$ & 57 & 1.26 & 1.143 & 0.2274 & Yes \\
\hline 9 & 01204000 & 0110 & $\mathrm{CT}$ & 81 & 0.74 & 0.693 & 0.1084 & Yes \\
\hline 10 & 01208925 & 0110 & $\mathrm{CT}$ & 41 & -0.01 & -0.007 & 0.1246 & Yes \\
\hline 11 & 01208950 & 0110 & $\mathrm{CT}$ & 54 & 0.85 & 0.765 & 0.1544 & Yes \\
\hline 12 & 01208990 & 0110 & $\mathrm{CT}$ & 52 & 0.09 & 0.078 & 0.1041 & Yes \\
\hline 13 & 01169000 & 0108 & MA & 74 & NA & 0.457 & 0.0983 & no-O \\
\hline 14 & 01169900 & 0108 & MA & 47 & NA & 0.709 & 0.1655 & no-O \\
\hline 15 & 01170100 & 0108 & MA & 46 & NA & 0.706 & 0.1679 & no-O \\
\hline 16 & 01171500 & 0108 & MA & 75 & NA & -0.348 & 0.0901 & no-O \\
\hline 17 & 01181000 & 0108 & MA & 78 & NA & 0.413 & 0.0913 & no-O \\
\hline 18 & 01198000 & 0110 & MA & 31 & NA & 0.4 & 0.1949 & no-P \\
\hline 19 & 01332000 & 0202 & MA & 62 & 0.65 & 0.592 & 0.1226 & Yes \\
\hline 20 & 01333000 & 0202 & MA & 64 & -0.06 & -0.056 & 0.0848 & Yes \\
\hline 21 & 01495000 & 0206 & MD & 127 & 0.08 & 0.074 & 0.0447 & Yes \\
\hline 22 & 01496000 & 0206 & MD & 37 & 0.87 & 0.75 & 0.2004 & Yes \\
\hline 23 & 01580000 & 0205 & $\mathrm{MD}$ & 87 & 0.17 & 0.16 & 0.069 & Yes \\
\hline 24 & 01582000 & 0206 & MD & 80 & 0.09 & 0.082 & 0.0695 & Yes \\
\hline 25 & 01583500 & 0206 & MD & 69 & 0.52 & 0.477 & 0.1056 & Yes \\
\hline 26 & 01584050 & 0206 & MD & 38 & 0.08 & 0.067 & 0.1382 & Yes \\
\hline 27 & 01584500 & 0206 & MD & 86 & -0.22 & -0.207 & 0.0714 & Yes \\
\hline 28 & 01586000 & 0206 & $\mathrm{MD}$ & 68 & 1.27 & 1.17 & 0.2003 & Yes \\
\hline 29 & 01586610 & 0206 & MD & 31 & NA & -0.304 & 0.1867 & no-P \\
\hline 30 & 01587500 & 0206 & MD & 32 & NA & 0.864 & 0.2403 & no-P \\
\hline 31 & 01588000 & 0206 & MD & 43 & 0.63 & 0.552 & 0.1621 & Yes \\
\hline 32 & 01591400 & 0206 & MD & 35 & NA & -0.664 & 0.2022 & no-P \\
\hline 33 & 01595500 & 0207 & MD & 63 & 1.38 & 1.259 & 0.2338 & Yes \\
\hline 34 & 01596500 & 0207 & MD & 65 & 0.67 & 0.617 & 0.1218 & Yes \\
\hline 35 & 01599000 & 0207 & MD & 84 & 0.46 & 0.433 & 0.0871 & Yes \\
\hline 36 & 01601500 & 0207 & MD & 84 & 0.92 & 0.858 & 0.1196 & Yes \\
\hline 37 & 01609000 & 0207 & MD & 39 & 0.47 & 0.407 & 0.1573 & Yes \\
\hline 38 & 01614500 & 0207 & MD & 94 & 0.27 & 0.257 & 0.0683 & Yes \\
\hline
\end{tabular}


Table 1. Streamgages that were considered for use in the regional skew analysis for parts of eastern New York and Pennsylvania.-Continued

[Locality abbreviations: CT, Connecticut; MA, Massachusetts; MD, Maryland; NJ, New Jersey; NY, New York; PA, Pennsylvania; VA, Virginia; VT, Vermont; WV, West Virginia. Other abbreviations: USGS, U.S. Geological Survey; EMA, expected moments algorithm; MSE, mean-square error; NA, not applicable because the streamgage was not used in the regional skew analysis; no-O, streamgage not used in regional skew analysis due to 4-digit hydrologic unit code outside the study area; no-P, streamgage not used in regional skew analysis due to Psuedo record length less than 36 years; no-R, streamgage not used in regional skew analysis due to redundancy]

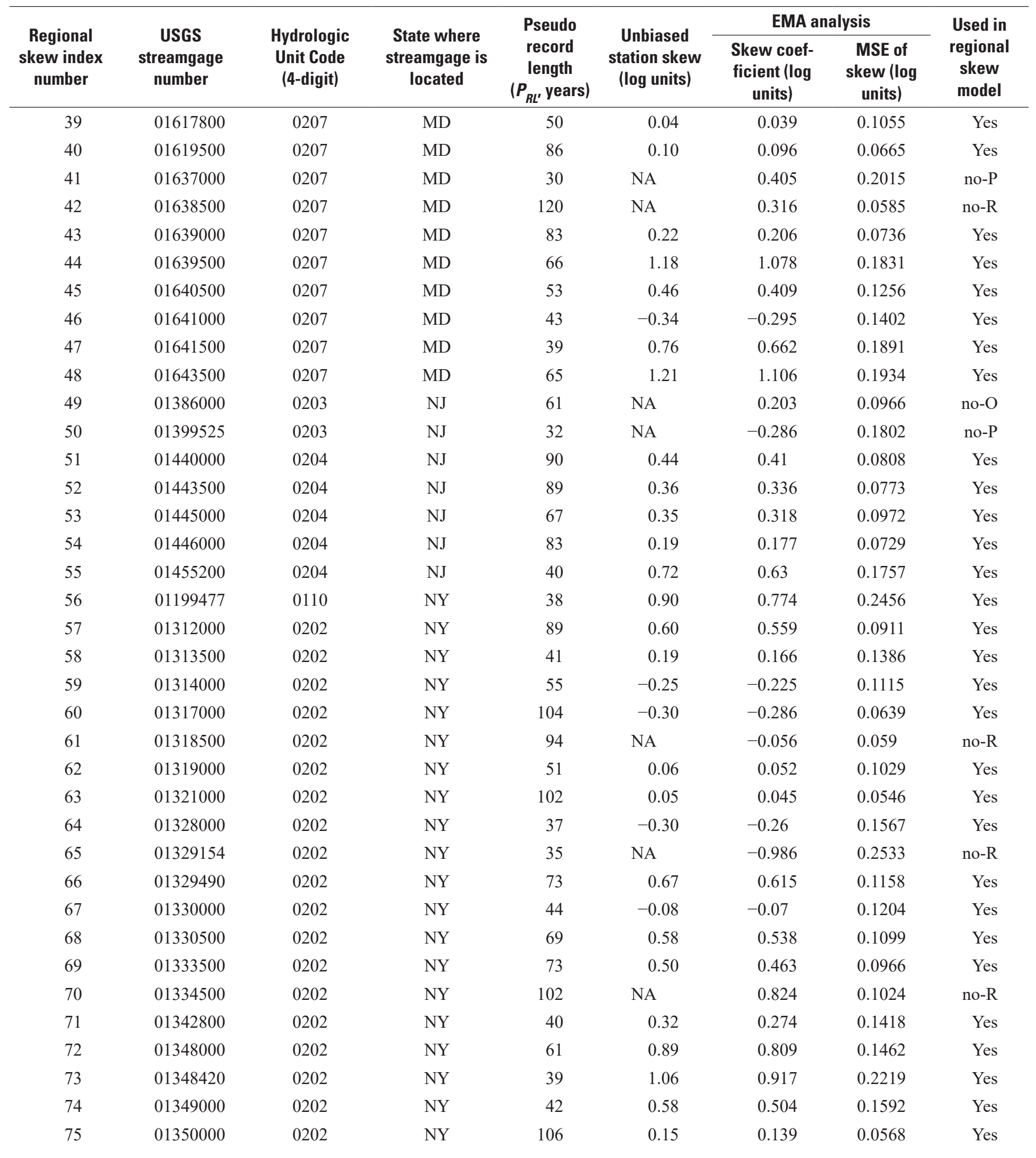


Table 1. Streamgages that were considered for use in the regional skew analysis for parts of eastern New York and Pennsylvania.-Continued

[Locality abbreviations: CT, Connecticut; MA, Massachusetts; MD, Maryland; NJ, New Jersey; NY, New York; PA, Pennsylvania; VA, Virginia; VT, Vermont; WV, West Virginia. Other abbreviations: USGS, U.S. Geological Survey; EMA, expected moments algorithm; MSE, mean-square error; NA, not applicable because the streamgage was not used in the regional skew analysis; no-O, streamgage not used in regional skew analysis due to 4-digit hydrologic unit code outside the study area; no-P, streamgage not used in regional skew analysis due to Psuedo record length less than 36 years; no-R, streamgage not used in regional skew analysis due to redundancy]

\begin{tabular}{|c|c|c|c|c|c|c|c|c|}
\hline \multirow[b]{2}{*}{$\begin{array}{c}\text { Regional } \\
\text { skew index } \\
\text { number }\end{array}$} & \multirow[b]{2}{*}{$\begin{array}{c}\text { USGS } \\
\text { streamgage } \\
\text { number }\end{array}$} & \multirow[b]{2}{*}{$\begin{array}{c}\text { Hydrologic } \\
\text { Unit Code } \\
\text { (4-digit) }\end{array}$} & \multirow[b]{2}{*}{$\begin{array}{l}\text { State where } \\
\text { streamgage is } \\
\text { located }\end{array}$} & \multirow{2}{*}{$\begin{array}{c}\text { Pseudo } \\
\text { record } \\
\text { length } \\
\left(P_{R L^{\prime}} \text { years }\right)\end{array}$} & \multirow[b]{2}{*}{$\begin{array}{l}\text { Unbiased } \\
\text { station skew } \\
\text { (log units) }\end{array}$} & \multicolumn{2}{|c|}{ EMA analysis } & \multirow{2}{*}{$\begin{array}{c}\text { Used in } \\
\text { regiona } \\
\text { skew } \\
\text { model }\end{array}$} \\
\hline & & & & & & $\begin{array}{c}\text { Skew coef- } \\
\text { ficient (log } \\
\text { units) }\end{array}$ & $\begin{array}{l}\text { MSE of } \\
\text { skew (log } \\
\text { units) }\end{array}$ & \\
\hline 76 & 01350120 & 0202 & NY & 38 & 0.63 & 0.541 & 0.1778 & Yes \\
\hline 77 & 01350140 & 0202 & NY & 39 & -0.21 & -0.186 & 0.1438 & Yes \\
\hline 78 & 01358500 & 0202 & NY & 59 & 1.47 & 1.336 & 0.2378 & Yes \\
\hline 80 & 01359750 & 0202 & NY & 38 & -0.19 & -0.164 & 0.133 & Yes \\
\hline 81 & 01361000 & 0202 & NY & 70 & 0.63 & 0.577 & 0.1117 & Yes \\
\hline 82 & 01361500 & 0202 & NY & 107 & -0.10 & -0.091 & 0.0571 & Yes \\
\hline 83 & 01362100 & 0202 & NY & 56 & 0.41 & 0.367 & 0.1168 & Yes \\
\hline 87 & 01365000 & 0202 & NY & 102 & -0.29 & -0.275 & 0.0631 & Yes \\
\hline 88 & 01365500 & 0202 & NY & 65 & 0.04 & 0.033 & 0.0828 & Yes \\
\hline 89 & 01368000 & 0202 & NY & 52 & 1.27 & 1.135 & 0.237 & Yes \\
\hline 90 & 01368500 & 0202 & NY & 51 & 1.01 & 0.901 & 0.1785 & Yes \\
\hline 91 & 01369000 & 0202 & NY & 40 & 0.56 & 0.488 & 0.1653 & Yes \\
\hline 92 & 01369500 & 0202 & NY & 42 & 0.28 & 0.242 & 0.1378 & Yes \\
\hline 93 & 01370000 & 0202 & NY & 54 & NA & 0.636 & 0.1453 & no-R \\
\hline 94 & 01371000 & 0202 & NY & 64 & -0.22 & -0.2 & 0.0841 & Yes \\
\hline 95 & 01371500 & 0202 & NY & 90 & 0.39 & 0.369 & 0.0785 & Yes \\
\hline 102 & 01413500 & 0204 & NY & 77 & 0.30 & 0.279 & 0.0838 & Yes \\
\hline 103 & 01414000 & 0204 & NY & 39 & 0.49 & 0.424 & 0.1632 & Yes \\
\hline 104 & 01414500 & 0204 & NY & 77 & 0.12 & 0.115 & 0.0745 & Yes \\
\hline 105 & 01415000 & 0204 & NY & 77 & 0.13 & 0.118 & 0.0747 & Yes \\
\hline 106 & 01418500 & 0204 & NY & 44 & NA & 0.103 & 0.1204 & no-R \\
\hline 107 & 01419500 & 0204 & NY & 39 & NA & 0.443 & 0.1633 & no-R \\
\hline 108 & 01420000 & 0204 & NY & 57 & -0.07 & -0.062 & 0.0948 & Yes \\
\hline 109 & 01420500 & 0204 & NY & 100 & 0.30 & 0.281 & 0.0669 & Yes \\
\hline 110 & 01421000 & 0204 & NY & 45 & NA & -0.039 & 0.1152 & no-R \\
\hline 111 & 01421900 & 0204 & NY & 57 & 0.08 & 0.071 & 0.0952 & Yes \\
\hline 112 & 01422500 & 0204 & NY & 55 & -0.24 & -0.217 & 0.1072 & Yes \\
\hline
\end{tabular}


Table 1. Streamgages that were considered for use in the regional skew analysis for parts of eastern New York and Pennsylvania.-Continued

[Locality abbreviations: CT, Connecticut; MA, Massachusetts; MD, Maryland; NJ, New Jersey; NY, New York; PA, Pennsylvania; VA, Virginia; VT, Vermont; WV, West Virginia. Other abbreviations: USGS, U.S. Geological Survey; EMA, expected moments algorithm; MSE, mean-square error; NA, not applicable because the streamgage was not used in the regional skew analysis; no-O, streamgage not used in regional skew analysis due to 4-digit hydrologic unit code outside the study area; no-P, streamgage not used in regional skew analysis due to Psuedo record length less than 36 years; no-R, streamgage not used in regional skew analysis due to redundancy]

\begin{tabular}{|c|c|c|c|c|c|c|c|c|}
\hline \multirow[b]{2}{*}{$\begin{array}{c}\text { Regional } \\
\text { skew index } \\
\text { number }\end{array}$} & \multirow[b]{2}{*}{$\begin{array}{c}\text { USGS } \\
\text { streamgage } \\
\text { number }\end{array}$} & \multirow[b]{2}{*}{$\begin{array}{l}\text { Hydrologic } \\
\text { Unit Code } \\
\text { (4-digit) }\end{array}$} & \multirow[b]{2}{*}{$\begin{array}{l}\text { State where } \\
\text { streamgage is } \\
\text { located }\end{array}$} & \multirow{2}{*}{$\begin{array}{c}\text { Pseudo } \\
\text { record } \\
\text { length } \\
\left(P_{R L^{\prime}} \text { years }\right) \\
\end{array}$} & \multirow[b]{2}{*}{$\begin{array}{l}\text { Unbiased } \\
\text { station skew } \\
\text { (log units) }\end{array}$} & \multicolumn{2}{|c|}{ EMA analysis } & \multirow{2}{*}{$\begin{array}{l}\text { Used in } \\
\text { regional } \\
\text { skew } \\
\text { model }\end{array}$} \\
\hline & & & & & & $\begin{array}{l}\text { Skew coef- } \\
\text { ficient (log } \\
\text { units) }\end{array}$ & $\begin{array}{l}\text { MSE of } \\
\text { skew (log } \\
\text { units) }\end{array}$ & \\
\hline 113 & 01423000 & 0204 & NY & 63 & -0.08 & -0.07 & 0.0869 & Yes \\
\hline 114 & 01425500 & 0204 & NY & 34 & NA & -0.004 & 0.1483 & no-P \\
\hline 115 & 01426000 & 0204 & NY & 40 & 0.62 & 0.542 & 0.1726 & Yes \\
\hline 117 & 01427500 & 0204 & NY & 55 & 0.52 & 0.469 & 0.1266 & Yes \\
\hline 118 & 01428000 & 0204 & NY & 44 & 1.12 & 0.984 & 0.1857 & Yes \\
\hline 119 & 01434025 & 0204 & $\mathrm{NY}$ & 30 & NA & 0.661 & 0.2272 & no-P \\
\hline 120 & 01435000 & 0204 & NY & 75 & -0.02 & -0.019 & 0.0716 & Yes \\
\hline 124 & 01500500 & 0205 & NY & 84 & 0.19 & 0.176 & 0.0712 & Yes \\
\hline 125 & 01501000 & 0205 & NY & 55 & -0.15 & -0.135 & 0.1006 & Yes \\
\hline 126 & 01501500 & 0205 & $\mathrm{NY}$ & 36 & 0.82 & 0.707 & 0.2023 & Yes \\
\hline 127 & 01502000 & 0205 & NY & 58 & -0.35 & -0.314 & 0.1089 & Yes \\
\hline 128 & 01502500 & 0205 & NY & 80 & -0.20 & -0.182 & 0.0756 & Yes \\
\hline 129 & 01503000 & 0205 & $\mathrm{NY}$ & 114 & NA & 0.041 & 0.0489 & no-R \\
\hline 130 & 01503980 & 0205 & $\mathrm{NY}$ & 49 & -0.03 & -0.024 & 0.1065 & Yes \\
\hline 131 & 01505000 & 0205 & $\mathrm{NY}$ & 77 & -0.09 & -0.081 & 0.073 & Yes \\
\hline 132 & 01505500 & 0205 & NY & 35 & NA & -0.367 & 0.1699 & no-P \\
\hline 139 & 01510500 & 0205 & NY & 43 & NA & 0.058 & 0.1208 & no-R \\
\hline 140 & 01510610 & 0205 & NY & 37 & 0.17 & 0.148 & 0.1472 & Yes \\
\hline 141 & 01513500 & 0205 & $\mathrm{NY}$ & 92 & 0.15 & 0.144 & 0.0638 & Yes \\
\hline 142 & 01514000 & 0205 & NY & 87 & 0.39 & 0.361 & 0.0797 & Yes \\
\hline 143 & 01520500 & 0205 & NY & 54 & NA & 0.459 & 0.1265 & no-R \\
\hline 144 & 01521596 & 0205 & NY & 36 & -1.65 & -1.41 & 0.173 & Yes \\
\hline 145 & 01522500 & 0205 & NY & 36 & -0.23 & -0.193 & 0.1535 & Yes \\
\hline 146 & 01526000 & 0205 & NY & 36 & -0.65 & -0.555 & 0.1847 & Yes \\
\hline 147 & 01526500 & 0205 & NY & 62 & NA & 0.456 & 0.1127 & no-R \\
\hline 148 & 01527000 & 0205 & NY & 49 & 0.74 & 0.66 & 0.1552 & Yes \\
\hline 149 & 01528000 & 0205 & NY & 59 & 0.53 & 0.481 & 0.1201 & Yes \\
\hline
\end{tabular}


Table 1. Streamgages that were considered for use in the regional skew analysis for parts of eastern New York and Pennsylvania.-Continued

[Locality abbreviations: CT, Connecticut; MA, Massachusetts; MD, Maryland; NJ, New Jersey; NY, New York; PA, Pennsylvania; VA, Virginia; VT, Vermont; WV, West Virginia. Other abbreviations: USGS, U.S. Geological Survey; EMA, expected moments algorithm; MSE, mean-square error; NA, not applicable because the streamgage was not used in the regional skew analysis; no-O, streamgage not used in regional skew analysis due to 4-digit hydrologic unit code outside the study area; no-P, streamgage not used in regional skew analysis due to Psuedo record length less than 36 years; no-R, streamgage not used in regional skew analysis due to redundancy]

\begin{tabular}{|c|c|c|c|c|c|c|c|c|}
\hline \multirow[b]{2}{*}{$\begin{array}{c}\text { Regional } \\
\text { skew index } \\
\text { number }\end{array}$} & \multirow[b]{2}{*}{$\begin{array}{c}\text { USGS } \\
\text { streamgage } \\
\text { number }\end{array}$} & \multirow[b]{2}{*}{$\begin{array}{c}\text { Hydrologic } \\
\text { Unit Code } \\
\text { (4-digit) }\end{array}$} & \multirow[b]{2}{*}{$\begin{array}{l}\text { State where } \\
\text { streamgage is } \\
\text { located }\end{array}$} & \multirow{2}{*}{$\begin{array}{c}\text { Pseudo } \\
\text { record } \\
\text { length } \\
\left(P_{R L^{\prime}} \text { years }\right)\end{array}$} & \multirow[b]{2}{*}{$\begin{array}{l}\text { Unbiased } \\
\text { station skew } \\
\text { (log units) }\end{array}$} & \multicolumn{2}{|c|}{ EMA analysis } & \multirow{2}{*}{$\begin{array}{c}\text { Used in } \\
\text { regiona } \\
\text { skew } \\
\text { model }\end{array}$} \\
\hline & & & & & & $\begin{array}{c}\text { Skew coef- } \\
\text { ficient (log } \\
\text { units) }\end{array}$ & $\begin{array}{l}\text { MSE of } \\
\text { skew (log } \\
\text { units) }\end{array}$ & \\
\hline 150 & 01530301 & 0205 & NY & 36 & -0.40 & -0.343 & 0.1654 & Yes \\
\hline 151 & 01530500 & 0205 & NY & 54 & -0.24 & -0.212 & 0.1094 & Yes \\
\hline 152 & 01531000 & 0205 & NY & 78 & 0.16 & 0.144 & 0.0753 & Yes \\
\hline 154 & 01428750 & 0204 & PA & 39 & 1.13 & 0.983 & 0.2346 & Yes \\
\hline 155 & 01431000 & 0204 & PA & 43 & 0.30 & 0.266 & 0.1383 & Yes \\
\hline 156 & 01438300 & 0204 & PA & 52 & 0.02 & 0.015 & 0.1217 & Yes \\
\hline 157 & 01439500 & 0204 & PA & 105 & 1.02 & 0.964 & 0.1161 & Yes \\
\hline 161 & 01449360 & 0204 & PA & 47 & -1.50 & -1.334 & 0.3029 & Yes \\
\hline 162 & 01450500 & 0204 & PA & 74 & 0.22 & 0.201 & 0.0821 & Yes \\
\hline 163 & 01451800 & 0204 & PA & 47 & -0.12 & -0.105 & 0.1205 & Yes \\
\hline 164 & 01453000 & 0204 & PA & 55 & 0.50 & 0.455 & 0.1254 & Yes \\
\hline 165 & 01459500 & 0204 & PA & 37 & 0.21 & 0.182 & 0.1504 & Yes \\
\hline 166 & 01470500 & 0204 & PA & 68 & -0.05 & -0.046 & 0.0798 & Yes \\
\hline 167 & 01470779 & 0204 & PA & 40 & -0.14 & -0.126 & 0.1353 & Yes \\
\hline 168 & 01472000 & 0204 & PA & 57 & 0.22 & 0.199 & 0.1025 & Yes \\
\hline 169 & 01472157 & 0204 & PA & 45 & 0.22 & 0.192 & 0.127 & Yes \\
\hline 176 & 01532000 & 0205 & PA & 100 & 0.52 & 0.486 & 0.0786 & Yes \\
\hline 177 & 01534000 & 0205 & PA & 100 & -0.33 & -0.308 & 0.0683 & Yes \\
\hline 178 & 01538000 & 0205 & PA & 94 & 0.22 & 0.21 & 0.0668 & Yes \\
\hline 179 & 01539000 & 0205 & $\mathrm{PA}$ & 75 & 0.43 & 0.4 & 0.0928 & Yes \\
\hline 180 & 01541000 & 0205 & PA & 101 & 0.73 & 0.687 & 0.0911 & Yes \\
\hline 181 & 01541500 & 0205 & PA & 47 & 0.25 & 0.219 & 0.124 & Yes \\
\hline 182 & 01542810 & 0205 & PA & 50 & 0.77 & 0.69 & 0.1561 & Yes \\
\hline 183 & 01543000 & 0205 & PA & 100 & 0.38 & 0.354 & 0.0709 & Yes \\
\hline 184 & 01543500 & 0205 & $\mathrm{PA}$ & 75 & NA & 0.398 & 0.0927 & no-R \\
\hline 185 & 01544500 & 0205 & PA & 73 & 0.66 & 0.611 & 0.1103 & Yes \\
\hline 186 & 01545600 & 0205 & PA & 49 & 0.82 & 0.729 & 0.1623 & Yes \\
\hline
\end{tabular}


Table 1. Streamgages that were considered for use in the regional skew analysis for parts of eastern New York and Pennsylvania.-Continued

[Locality abbreviations: CT, Connecticut; MA, Massachusetts; MD, Maryland; NJ, New Jersey; NY, New York; PA, Pennsylvania; VA, Virginia; VT, Vermont; WV, West Virginia. Other abbreviations: USGS, U.S. Geological Survey; EMA, expected moments algorithm; MSE, mean-square error; NA, not applicable because the streamgage was not used in the regional skew analysis; no-O, streamgage not used in regional skew analysis due to 4-digit hydrologic unit code outside the study area; no-P, streamgage not used in regional skew analysis due to Psuedo record length less than 36 years; no-R, streamgage not used in regional skew analysis due to redundancy]

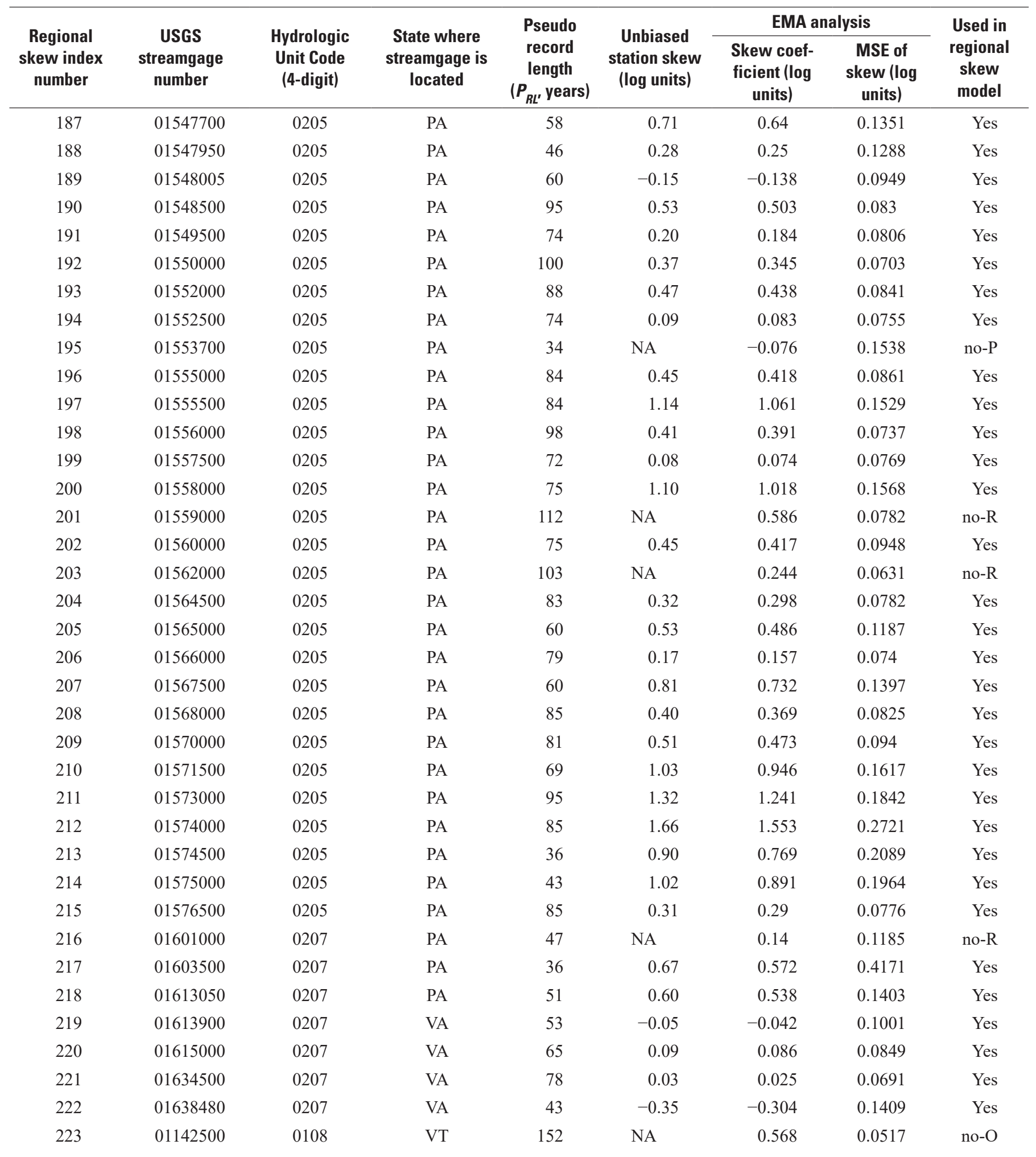


Table 1. Streamgages that were considered for use in the regional skew analysis for parts of eastern New York and Pennsylvania.-Continued

[Locality abbreviations: CT, Connecticut; MA, Massachusetts; MD, Maryland; NJ, New Jersey; NY, New York; PA, Pennsylvania; VA, Virginia; VT, Vermont; WV, West Virginia. Other abbreviations: USGS, U.S. Geological Survey; EMA, expected moments algorithm; MSE, mean-square error; NA, not applicable because the streamgage was not used in the regional skew analysis; no-O, streamgage not used in regional skew analysis due to 4-digit hydrologic unit code outside the study area; no-P, streamgage not used in regional skew analysis due to Psuedo record length less than 36 years; no-R, streamgage not used in regional skew analysis due to redundancy]

\begin{tabular}{|c|c|c|c|c|c|c|c|c|}
\hline \multirow[b]{2}{*}{$\begin{array}{c}\text { Regional } \\
\text { skew index } \\
\text { number }\end{array}$} & \multirow[b]{2}{*}{$\begin{array}{c}\text { USGS } \\
\text { streamgage } \\
\text { number }\end{array}$} & \multirow[b]{2}{*}{$\begin{array}{c}\text { Hydrologic } \\
\text { Unit Code } \\
\text { (4-digit) }\end{array}$} & \multirow[b]{2}{*}{$\begin{array}{l}\text { State where } \\
\text { streamgage is } \\
\text { located }\end{array}$} & \multirow{2}{*}{$\begin{array}{c}\text { Pseudo } \\
\text { record } \\
\text { length } \\
\left(P_{R L^{\prime}} \text { years }\right)\end{array}$} & \multirow[b]{2}{*}{$\begin{array}{c}\text { Unbiased } \\
\text { station skew } \\
\text { (log units) }\end{array}$} & \multicolumn{2}{|c|}{ EMA analysis } & \multirow{2}{*}{$\begin{array}{c}\text { Used in } \\
\text { regiona } \\
\text { skew } \\
\text { model }\end{array}$} \\
\hline & & & & & & $\begin{array}{c}\text { Skew coef- } \\
\text { ficient (log } \\
\text { units) }\end{array}$ & $\begin{array}{l}\text { MSE of } \\
\text { skew (log } \\
\text { units) }\end{array}$ & \\
\hline 224 & 01150900 & 0108 & VT & 29 & NA & 1.491 & 0.5984 & no-O \\
\hline 225 & 01155350 & 0108 & VT & 30 & NA & 0.714 & 0.233 & no-O \\
\hline 226 & 01329000 & 0202 & VT & 59 & NA & 0.458 & 0.117 & no-R \\
\hline 228 & 01608500 & 0207 & WV & 97 & 0.61 & 0.578 & 0.0877 & Yes \\
\hline 229 & 01611500 & 0207 & WV & 99 & -0.06 & -0.057 & 0.056 & Yes \\
\hline 230 & 01614000 & 0207 & WV & 81 & 0.20 & 0.185 & 0.0718 & Yes \\
\hline 231 & 01616500 & 0207 & WV & 71 & 0.14 & 0.126 & 0.0803 & Yes \\
\hline
\end{tabular}




\section{Appendix 1. Assessment of a Regional Skew Model for Parts of Eastern New York and Pennsylvania by Using Monte Carlo Simulations}

This appendix provides a graphical assessment of the Bayesian weighted least squares/Bayesian generalized least squares (B-WLS/B-GLS) model of regional skew for parts of eastern New York and Pennsylvania that is described in this report. Observed, unbiased station skews are depicted in figure 1.1 along with contour lines and shading to provide a sense of geographic patterns in the skews.

Monte Carlo simulations were used to determine whether geographic patterns observed in the station skews are evidence of significant model misspecification or an artifact of randomsampling variability that is possibly confounded by the covariance structure of the errors. The Monte Carlo simulations were generated from a multivariate normal distribution with a mean equal to the constant from the regional skew model and a covariance matrix identical to the covariance matrix used in the regional skew model. The constant model of skew in the study area is:

$$
\hat{\gamma}_{B-W L S / B-G L S}=0.32+\varepsilon,
$$

where

$\varepsilon \quad$ represents the total error, and

$$
\varepsilon \sim N(0, \operatorname{Var}(\varepsilon)),
$$

where

$N \quad$ signifies a normal distribution of the total error in the constant regional skew model determined in the B-GLS analysis.

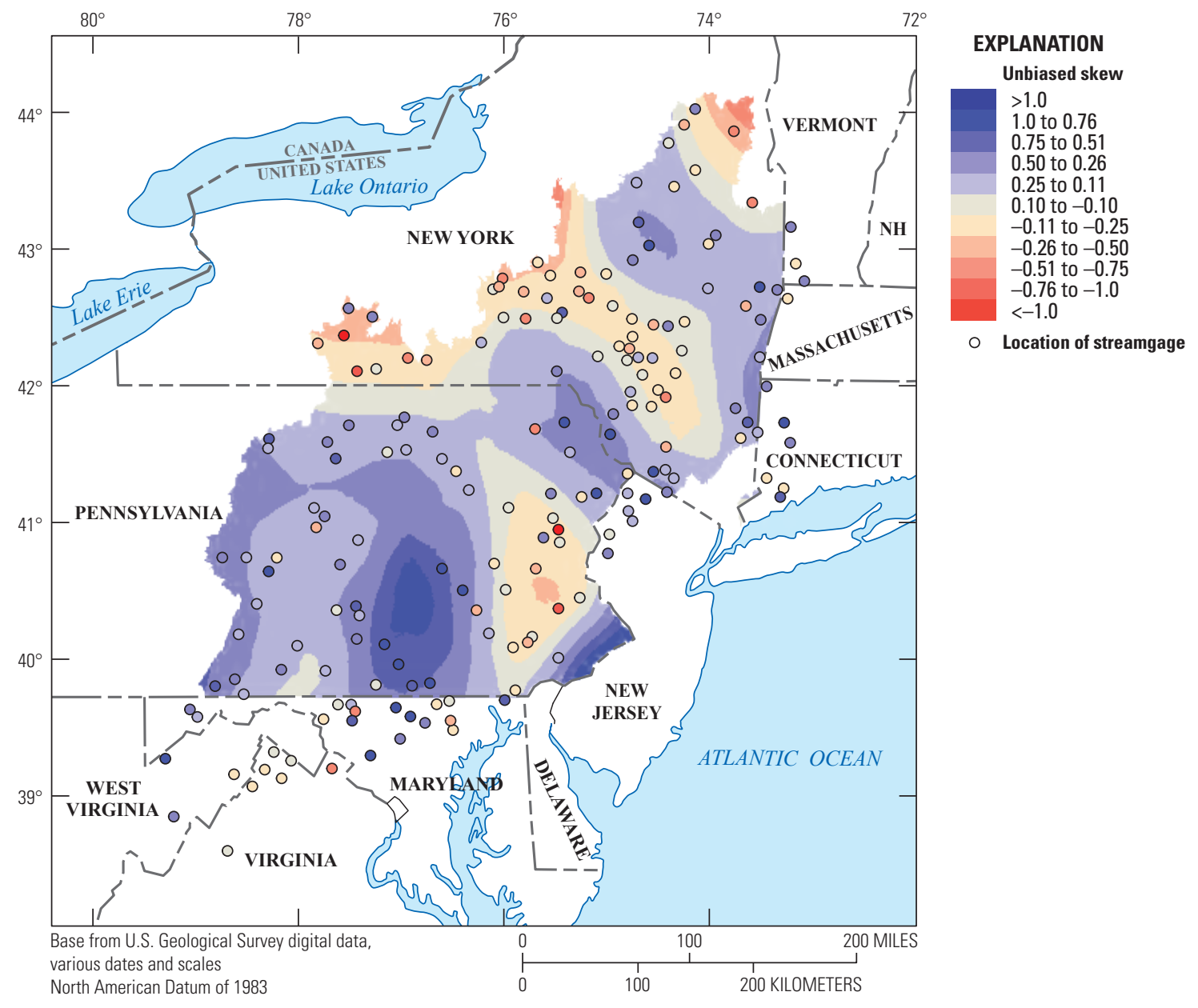

Figure 1.1. Contour map of unbiased station skews for the 183 streamgages that were used in the regional skew analysis for parts of eastern New York and Pennsylvania. 
As described in equation 1.2, the $\operatorname{Var}(\varepsilon)$ can be described as

$$
\left[\varepsilon \varepsilon^{T}\right]=\boldsymbol{\Lambda}_{B-G L S}\left(\sigma_{\delta, B-G L S}^{2}\right)=\sigma_{\delta, B-G L S}^{2} \boldsymbol{I}+\boldsymbol{\Sigma}(\hat{\gamma})
$$

where

$$
\begin{gathered}
\varepsilon^{T} \quad \text { is the transformation of } \varepsilon, \\
\boldsymbol{\Lambda}_{B-G L S}\left(\sigma_{\delta, B-G L S}^{2}\right) \quad \text { is the }(n \times n) \text { B-GLS covariance matrix, } \\
\sigma_{\delta, B-G L S}^{2} \quad \begin{aligned}
\text { is the B-GLS variance of the underlying } \\
\text { model error } \delta,
\end{aligned} \\
\begin{aligned}
\boldsymbol{I}(\hat{\gamma}) \quad & \text { is an }(n \times n) \text { identity matrix, and } \\
& \text { is the full }(n \times n) \text { covariance matrix of the } \\
& \text { sampling errors for each streamgage }(n) .
\end{aligned}
\end{gathered}
$$

The covariance matrix of the sampling errors is made up of the sampling variances of the unbiased station skew $\left(\operatorname{Var}\left[\hat{\gamma}_{i}\right]\right)$ and the covariances of the skewness estimators $\left(\hat{\gamma}_{i}\right)$. The off-diagonal values of $\Sigma(\hat{\gamma})$ are determined by the cross correlation of concurrent gaged annual peak flows and the $c f$ factor (see equation 3 in Martins and Stedinger, 2002). The model error variance $\sigma_{\delta}^{2}$ for the constant model is
0.10 (table 3) and was used in the Monte Carlo simulations. The covariance matrix $\Sigma(\hat{\gamma})$ used in the Monte Carlo simulations is the same as that used in the B-WLS/B-GLS regression analysis (see eqs. 18 and 19 in the report).

The results of the Monte Carlo simulations are depicted graphically in 20 realizations (fig. 1.2) of the expected patterns in the station skew if the station skews are normally distributed with a mean equal to 0.32 and a covariance matrix given by equation 1.3. The Monte Carlo simulations reveal no structure in the pattern of the station skews that is consistent with the observed pattern of the station skews in the constant model (fig. 1.1). Therefore, it seems reasonably safe to conclude that, despite the geographic patterns observed in the station skews, there is little evidence of a lack of fit.

\section{Reference Cited}

Martins, E.S., and Stedinger, J.R., 2002, Cross correlations among estimators of shape: Water Resources Research, v. 38, no. 11, p. 34-1 to 34-7. [Also available at https://doi.org/10.1029/2002WR001589.] 

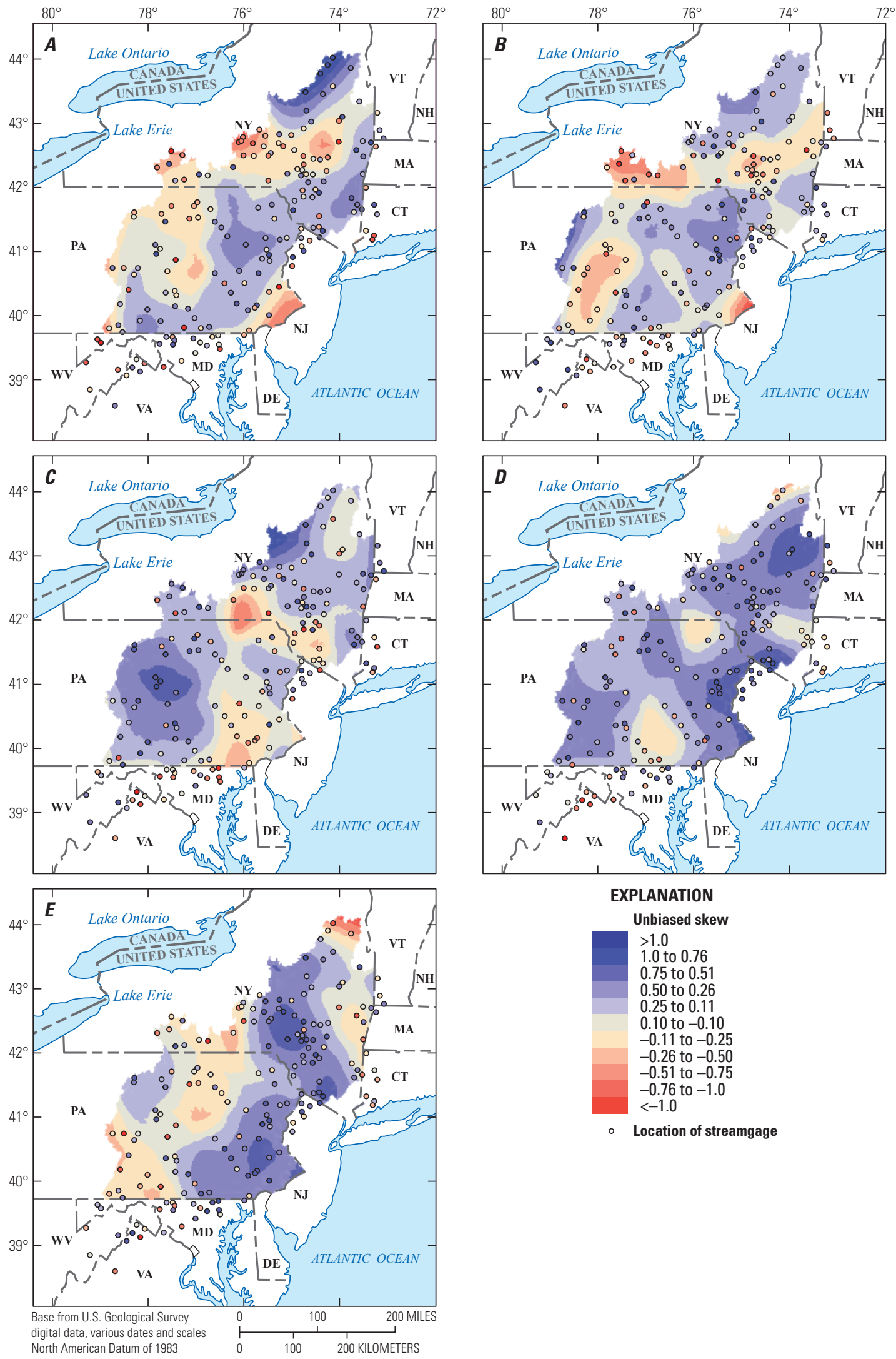

EXPLANATION

Unbiased skew

$>1.0$

1.0 to 0.76

0.75 to 0.5

0.50 to 0.26

0.25 to 0.11

0.10 to -0.10

-0.11 to -0.25

-0.26 to -0.50

-0.51 to -0.75

-0.76 to -1.0

$<-1.0$

- Location of streamgage

Figure 1.2. Contour maps showing the results of 20 Monte Carlo simulations $(A-T)$ of unbiased station skew at 183 streamgages that were used in the regional skew analysis for parts of eastern New York and Pennsylvania. Simulations are normally distributed to the constant skew model and covariance matrix. 

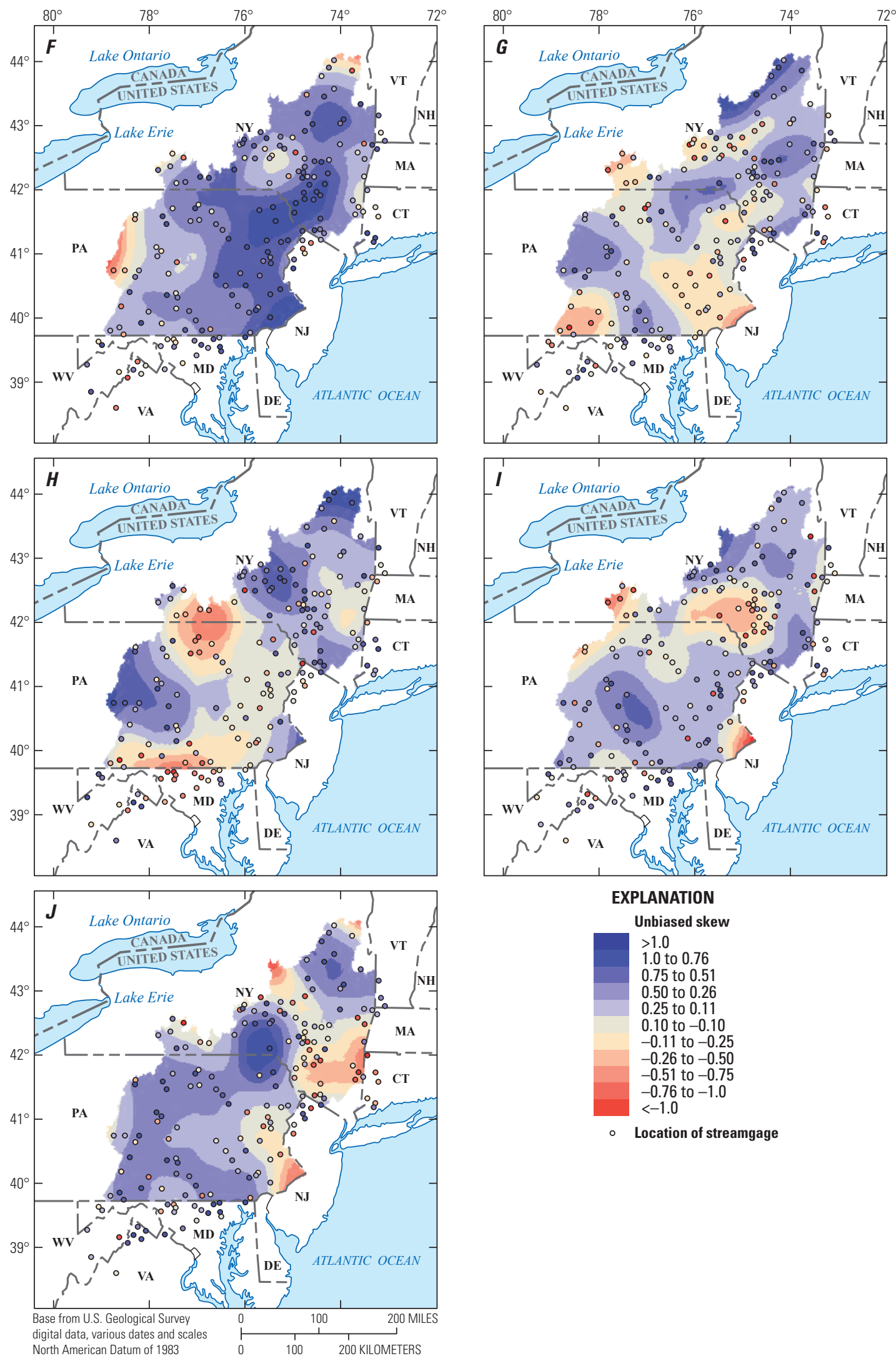

\section{EXPLANATION}

Unbiased skew

$>1.0$

1.0 to 0.76

0.75 to 0.51

0.50 to 0.26

0.25 to 0.11

0.10 to -0.10

-0.11 to -0.25

-0.26 to -0.50

-0.51 to -0.75

-0.76 to -1.0

$<-1.0$

- Location of streamgage

Figure 1.2.-Continued 

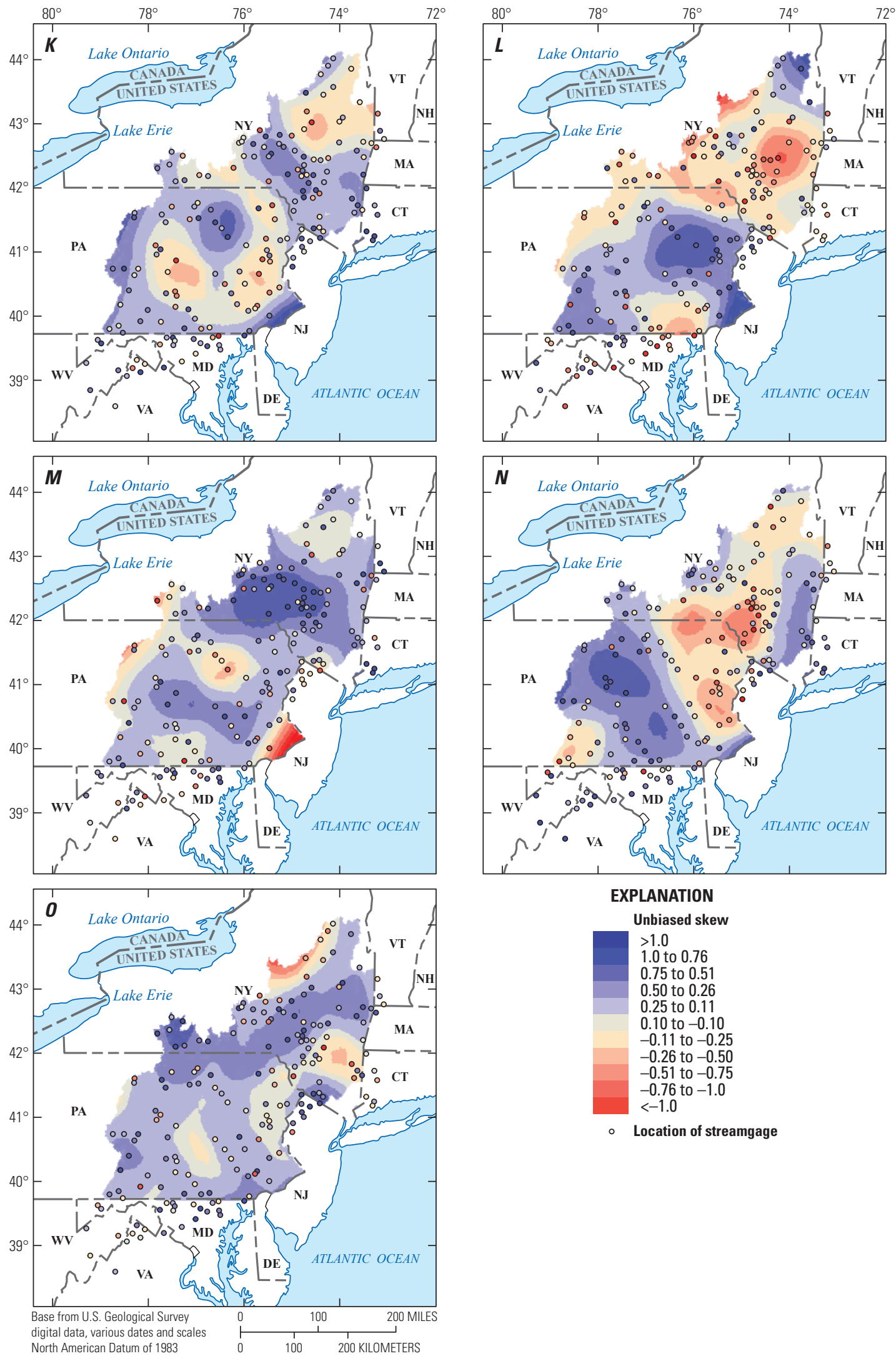

\section{EXPLANATION}

Unbiased skew

$>1.0$

1.0 to 0.76

0.75 to 0.51

0.50 to 0.26

0.25 to 0.11

0.10 to -0.10

-0.11 to -0.25

-0.26 to -0.50

-0.51 to -0.75

-0.76 to -1.0

$<-1.0$

- Location of streamgage

Figure 1.2.-Continued 

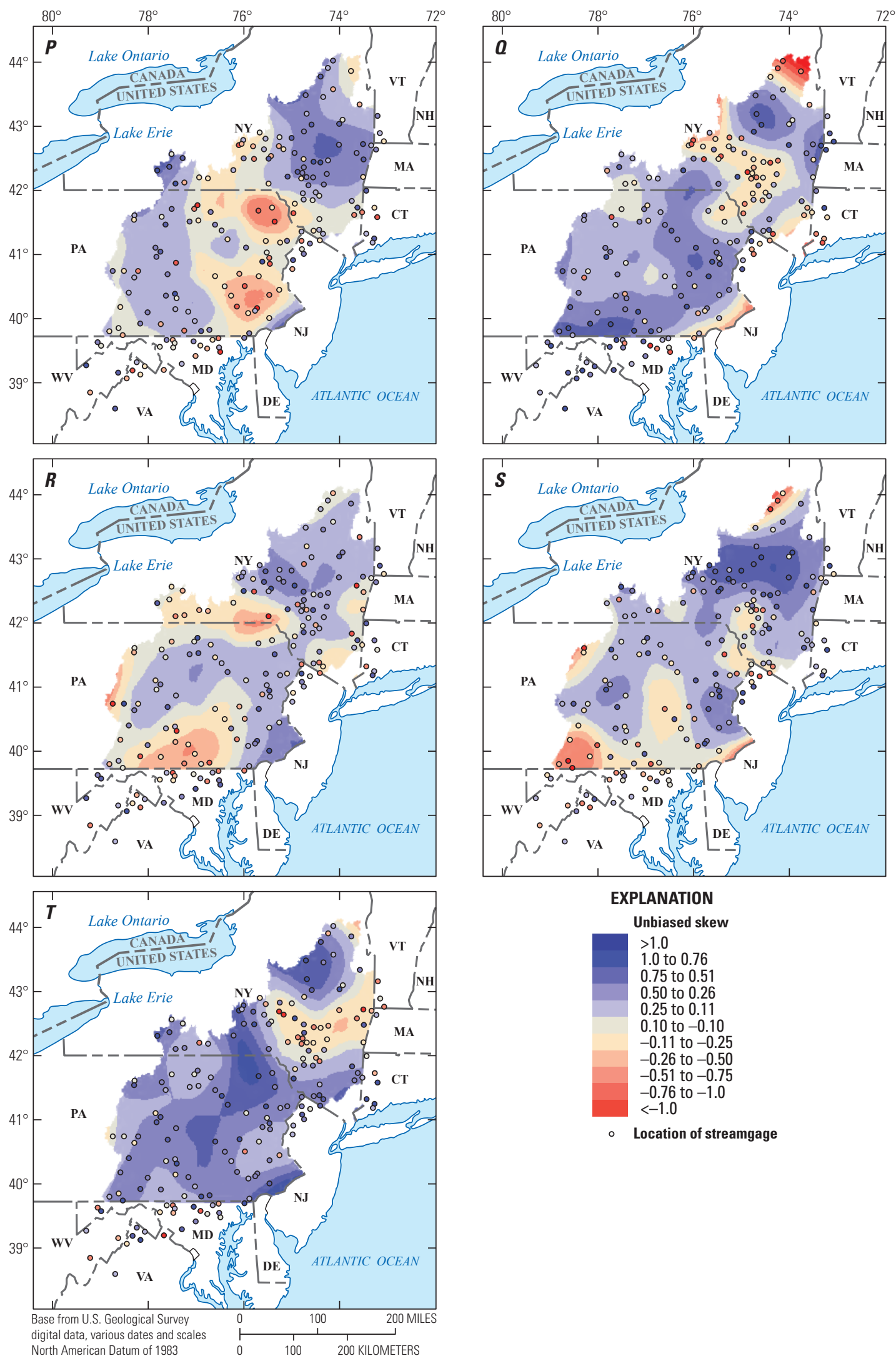

\section{EXPLANATION}

Unbiased skew

$>1.0$

1.0 to 0.76

0.75 to 0.51

0.50 to 0.26

0.25 to 0.11

0.10 to -0.10

-0.11 to -0.25

-0.26 to -0.50

-0.51 to -0.75

-0.76 to -1.0

$<-1.0$

- Location of streamgage

Figure 1.2.-Continued 

